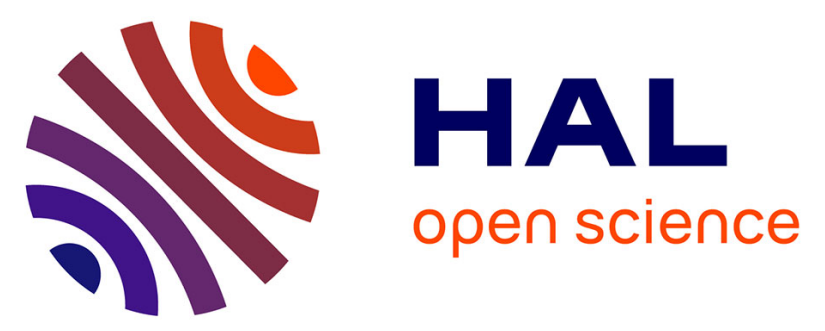

\title{
Non-destructive methods for measuring chloride ingress into concrete: State-of-the-art and future challenges
}

\author{
Marcela Torres-Luque, Emilio Bastidas-Arteaga, Franck Schoefs, Mauricio
} Sánchez-Silva, Johann F. Osma

\section{- To cite this version:}

Marcela Torres-Luque, Emilio Bastidas-Arteaga, Franck Schoefs, Mauricio Sánchez-Silva, Johann F. Osma. Non-destructive methods for measuring chloride ingress into concrete: Stateof-the-art and future challenges. Construction and Building Materials, 2014, 68, pp.68-81. 10.1016/j.conbuildmat.2014.06.009 . hal-01023391

\section{HAL Id: hal-01023391 \\ https://hal.science/hal-01023391}

Submitted on 17 Jul 2014

HAL is a multi-disciplinary open access archive for the deposit and dissemination of scientific research documents, whether they are published or not. The documents may come from teaching and research institutions in France or abroad, or from public or private research centers.
L'archive ouverte pluridisciplinaire HAL, est destinée au dépôt et à la diffusion de documents scientifiques de niveau recherche, publiés ou non, émanant des établissements d'enseignement et de recherche français ou étrangers, des laboratoires publics ou privés. 


\title{
Non-destructive methods for measuring chloride ingress into concrete: State-of-the-art and future challenges
}

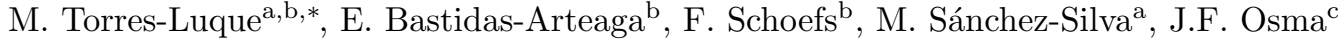 \\ ${ }^{a}$ Department of Civil and Environmental Engineering, Universidad de los Andes, Carrera 1E N. 19A-40 Edificio \\ $M L$, Piso 6. Bogotá, Colombia \\ ${ }^{b}$ LUNAM Université, Université de Nantes-Ecole Centrale Nantes, Institute for Research in Civil and Mechanical \\ Engineering (GeM)/Sea and Littoral Research Institute CNRS UMR 6183/FR 3473,2 rue de la Houssinière BP \\ 92208, 44322 Nantes, France \\ ${ }^{c}$ CMUA, Department of Electrical and Electronics Engineering, Universidad de los Andes, Carrera 1E N. 19A-40 \\ Edificio ML, Piso 7. Bogotá, Colombia
}

\begin{abstract}
Chloride ingress is one of the major causes of reinforced concrete (RC) deterioration. Free chloride induces the corrosion of rebars, reducing the material strength, and therefore, the structural behavior. This paper highlights the importance of chloride content measuring, and also summarizes the state of the art of non-destructive and in situ techniques for measuring chloride content into concrete structures. These techniques have been developed over the past twenty years, and they have been shown as good alternatives in durability field. They are based on three methods: electrical resistivity (ER), ion selective electrode (ISE) and optical fiber sensors (OFS).

Keywords: Reinforced concrete, Durability, Chloride ingress, Corrosion, Non-destructive techniques
\end{abstract}

\section{Introduction}

Chloride ingress is one of the major causes of reinforced concrete (RC) deterioration affecting structural serviceability and safety [1, 2]. Chloride-induced corrosion begins when the concentration of chloride at the steel bars reaches a threshold value that destroys a thin passive layer of corrosion products (caused by the high alkalinity of concrete at the end of construction), which protects steel bars against corrosion. After corrosion initiation, there is a premature deterioration caused by various mechanisms: loss of reinforcement section, loss of steel-concrete bond, concrete cracking

\footnotetext{
*Principal corresponding author

Email address: mm.torres118@uniandes.edu.co, Phone: +57 3107659440 (M. Torres-Luque)
} 
and delamination. After steel corrosion starts, the RC physical and mechanical properties decay at rate that depends on the environmental conditions. This deterioration process generates larger repair and maintenance costs with severe impact on the durability and life-cycle performance.

In 1991, the Federal Highway Administration (FHWA) found that about 39\% of highway structures present defects due to reinforcement corrosion. This means that about 134,000 structures are labeled as damaged and require urgent repairs [3]. In 2002 the FHWA and the National Association of Corrosion Engineers International (NACE) stated that approximately $15 \%$ of the total bridges in the USA were structurally deficient due to rebar corrosion. They estimated that the replacement and maintenance of these structures cost about USD $\$ 8.3$ billion [4. More recently, the ASCE 2009 Report card for America's Infrastructure showed that USD $\$ 2,2$ trillion are necessary to be invested over 5 years to bring the American structures up to appropriate conditions [5]. In Europe, much of the transport infrastructure in the Atlantic Area is over 50 years old and many structures are in severely deteriorated conditions due to the high aggressiveness of marine environments [6]. For instance, in Denmark the damage costs, due to maintenance programs and traffic delay, vary between $15 \%$ and $40 \%$ of construction costs [7].

The measurement of chloride content at the concrete cover could be used to estimate the risk of corrosion initiation, and therefore, to optimize repair and maintenance costs. There are many lab techniques and field measurements for measuring chloride content in RC. The most popular techniques are potentiometric and Volhard methods. They measure free and total chlorides in concrete cores extracted from in service structures. However, these techniques are mostly semidestructive, time-consuming and costly. Furthermore, their destructive nature lead to additional indirect costs such as traffic delay, traffic management, road closures and lost productivity, which increase costs further $[8]$.

Currently, several research groups are working on developing non-destructive techniques (NDT) to survey or measure chloride ingress in concrete. NDT imply methods that do not change the environment and the futures usefulness of the material where the measurement is taken, for example techniques that works with external or embedded equipments [9, 10. The most studied and developed general methods could be classified in: (i) ion selective electrodes (ISE) [1, 12, 10, 13, 14, 15, (ii) electrical resistivity (ER) [16, 17, 18, 7, 19, 8, and (iii) optical fiber sensor (OFS) 20, 21, 22, 23, 24. Other methods such as grounding penetrating radars (GPR), capacitive methods, or electrochemical impedance spectroscopy (EIS) have been used for corrosion 
assessment [13, 25, 26, 27, for detection of chlorides [28], or for chloride diffusion coefficient estimation [29, 30, 31] in laboratory concrete specimens; however, until now, there is not NDTs for chloride concentration based on electric capacitance or electrochemical impedance.

ISE, ER and OFS have shown some advantages: ISE shows a good chemical stability in aggressive environments, ER is sensitive to chloride presence, and OFS shows better sensitivity to chlorides than the others. However, there are some problems that have not been solved yet. For instance, most of these methods are very sensitive to changes in the conditions inside the concrete structure (e.g., changes in temperature, relative humidity, pH), and some of them require a careful calibration process. The results derived from these techniques could provide information to improve the understanding and modeling of chloride ingress mechanisms under real exposure conditions. Since non destructive measurements could be taken at several points and times, the results are useful for uncertainties and spatial variability quantification. This will allow developing probabilistic determination models for determining and predicting structural lifetime and repair/maintenance scheduler [32, 33, 34, 35].

The objective of this paper is to present a critical review of the advantages and disadvantages of the main and latest in situ non-destructive methods to determine and to assess chloride concentration in RC structures. Moreover, the paper presents an overview of the general critical aspects that influence corrosion risk deepening in chloride ingress and their physical and chemical impact on structures.

The paper is structured as follows. Section 2 presents a summary about corrosion in RC structures; this part takes into account the main causes of the corrosion processes. Section 3 points out the importance of chloride presence in RC durability, the critical chloride content for corrosion initiation and the importance of assessing chloride concentration. Section 4 briefly describes laboratory and field techniques for measuring chloride content. Section 5 explains the physical and chemical principles of non-destructive methods for assessing chloride concentration in concrete structures. Based on the literature review of non-destructive methods/techniques, Section 6 makes a critical comparison between those techniques focus on invasiveness, precision, robustness and fabrication. After, Section 7 remarks the main challenges for the future in non-destructive measuring of chloride concentration. Finally, Section 8 presents the conclusions of this study. 


\section{Critical issues in corrosion initiation}

Corrosion is a natural degradation process of metals, which leads to steel mass loss and dimensional changes [36. Steel corrosion on steel and RC structures may affect significantly their lifetime. This section presents an overview of corrosion in RC structures including the influencing factors as well as its effects on the durability.

\subsection{Description of corrosion process}

At the end of construction, the reinforcement in $\mathrm{RC}$ structures is physically protected from corrosion by the barrier imposed by the concrete cover and by a protective passive layer of insoluble corrosion products around rebars. Under normal conditions, the protection provided by the concrete inhibits corrosion initiation because: (1) the $\mathrm{pH}$ of concrete is very high ( $\mathrm{pH}$ up to 13) and (2) its electrical conductivity is low. Nevertheless, during the structural lifetime external actions such as the penetration of aggressive species $\left(\mathrm{Cl}^{-},\left(\mathrm{SO}_{4}\right)^{-2}, \mathrm{CO}_{2}, \mathrm{H}_{2} \mathrm{O}, \mathrm{O}_{2}\right)$ favor electrochemical corrosion. Corrosion could be divided into primary and secondary electrochemical processes. In the primary electrochemical processes, iron from rebar dissolves in the pore water:

$$
2 \mathrm{Fe} \longrightarrow 2 \mathrm{Fe}^{2+}+4 e^{-} \longrightarrow 2 \mathrm{Fe}^{3+}+6 e^{-} \quad \text { Anodic reaction }
$$

To preserve the electrical neutrality, the electrons released must be used, and a second chemical reaction takes place in elsewhere on the steel surface:

$$
4 H^{+}+4 e^{-} \longrightarrow H_{2} \quad \text { Cathodic reaction }
$$

The corrosion products are generated during the secondary electrochemical processes. Various corrosion products can be produced depending mainly on the $\mathrm{pH}$ of the solution, oxygen supply and moisture content. These reactions consume the $\mathrm{Fe}^{2+}$ produced in the primary processes, and 


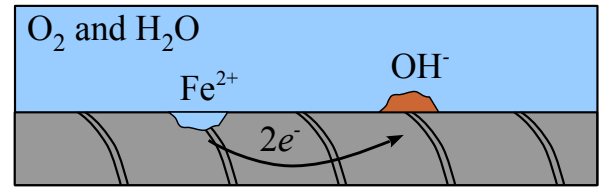

Anode

Cathode

Figure 1: Corrosion cell.

take hydrogen and oxygen from pore water to form pits in the material:

$$
\begin{aligned}
2 \mathrm{Fe}^{2+}+4 \mathrm{H}_{2} \mathrm{O} & \longrightarrow 2 \mathrm{Fe}(\mathrm{OH})_{2}+4 \mathrm{H}^{+} \\
4 \mathrm{Fe}(\mathrm{OH})_{2}+\mathrm{O}_{2}+2 \mathrm{H}_{2} \mathrm{O} & \longrightarrow 4 \mathrm{Fe}(\mathrm{OH})_{3} \\
2 \mathrm{Fe}(\mathrm{OH})_{3} & \longrightarrow \mathrm{Fe}_{2} \mathrm{O}_{3} \cdot \mathrm{H}_{2} \mathrm{O}+2 \mathrm{H}_{2} \mathrm{O}
\end{aligned}
$$

Note that equations 1-5 apply to any general corrosion process (Figure 1) out of which chloride induced corrosion is a particular case where chloride ions, come from the environment, reach the rebar and reduce the $\mathrm{pH}$ breaking the passive shield of the rebar and allowing corrosion processes.

It is important to stress that corrosion products (oxides - $\mathrm{Fe}_{2} \mathrm{O}_{3^{-}}$and hydroxides $-\mathrm{Fe}(\mathrm{OH})_{3^{-}}$) are 4 to 7 times more voluminous than steel, which is the main cause for local stress increase and crack initiation and propagation within the RC structures 37, 38, 39, 40, 41.

\subsection{Main factors that influence corrosion of $R C$ structures}

The main factors that determine the performance of RC structures when exposed to corrosive environments are (see Figure 2):

1. design and construction practices, and

2. environmental factors.

\subsubsection{Design and construction practices}

It is well known [33, 34] that design and construction choices and practices significantly influence the durability of RC structures in agressive environments (e.g., chloride/sulphate-contaminated). The selection of appropriate values for $\mathrm{w} / \mathrm{c}$ ratio, nominal concrete cover thickness, and concrete strength during the design combined with efficient construction practices (proper curing, casting, etc.) are paramount for the durability of RC structures (Figure 2). For instance, for a cover 
thickness of $30 \mathrm{~mm}$ a w/c ratio of 0.4 and 3 days curing is more efficient for reducing chloride ingress than those with the same thickness, w/c ratio of 0.5 and 1 day curing [42].

Concerning design parameters, larger cover increases the time required for steel bar corrosion initiation. Higher concrete strength, smaller w/c ratio, and the addition of some admixtures reduce the chloride ingress, moisture and oxygen diffusion rates into concrete. Low contents of cement allow the formation of honeycombs and surface defects which increase the penetration of aggressive agents, e.g., $\mathrm{Cl}^{-}, \mathrm{H}_{2} \mathrm{O}, \mathrm{O}_{2}$, and $\mathrm{CO}_{2}$ [43. Several studies have shown that the addition of some admixtures such as fly ash, silica fume, slag and metakaolin improve the RC durability in marine environments [5, 44]. These admixtures improve the distribution of pore size, increase chloride binding, and decrease chloride permeability. Finally, the size of aggregates determines the permeability of concrete; i.e., larger aggregate sizes increase concrete permeability by accelerating the rate of penetration of aggressive agents [43.

Construction practices define important concrete properties (porosity, permeability, etc.) that determine the system durability (Figure 2). For example, inappropriate curing techniques increase porosity, which defines the physical characteristics of the concrete matrix against chloride penetration [42, 45]. Furthermore, the surface condition of reinforcing steel significantly affects its behavior against corrosion initiation [46, 47, 48]. In this regard, some studies [49] have recognized that rough steel surfaces have more active points than smooth surfaces, and in these points corrosion processes can be accelerated. Corrosion processes are also faster in rebars with mill-scale surface treatment than in those with polished treatment [50, 48. Also, it has been found that the presence of stirrups increases macrocell corrosion of steel [46]. Finally, the existence of gaps in the concrete-steel interface due to casting direction accelerates the corrosion process [50, 48].

On the whole, the design of durable RC structures could be improved by looking for consistency with the exposure conditions (w/c ratio, cement content, use of admixture, nominal cover thickness, etc.). From a construction practice perspective, chloride ingress and corrosion damage can be reduced by taking actions such as: aggregate washing, control of chlorides in water, proper curing, etc. Finally, other factors such as the quality of the execution and the complexity of the structural member also defines the effective concrete cover thickness by increasing or decreasing the length of corrosion initiation stage. 


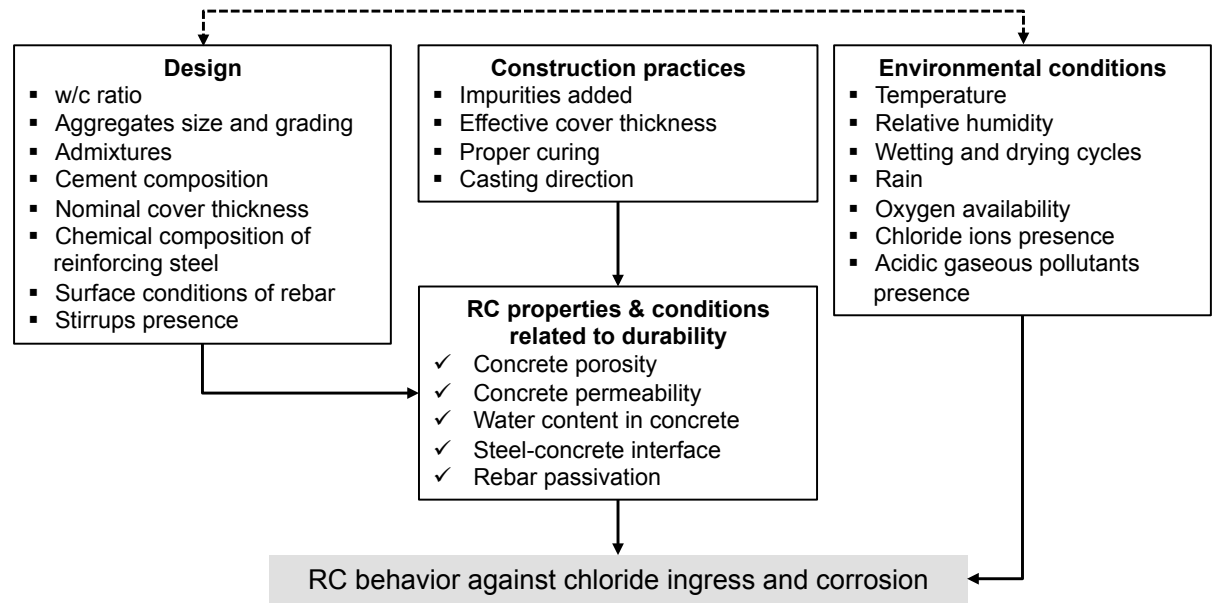

Figure 2: Factors influencing chloride ingress and corrosion processes in RC

\subsubsection{Environmental conditions}

The RC behavior against corrosion propagation depends also on the exposure conditions. Chloride ingress depends on the surface chloride concentration and on other environmental factors such as temperature and relative humidity [51]. Larger temperature and optimal relative humidity accelerate chloride ingress and corrosion propagation processes. These processes are also highly influenced by the presence of water (e.g. sea water, rain or wetting and drying cycles), that increases chloride ingress [52] or corrosion rates. Therefore, deterioration processes will have different kinematics depending upon the macro-environments (environmental conditions for a given place) and/or micro-environments (submerged, tidal, splash or atmospheric conditions in marine environments) 53 .

Another important environmental factor is the presence of acidic gaseous pollutants such as: carbon dioxide, sulphur dioxide, and nitrogen oxides [54, 55, 1]. These acidic compounds are produced by industrial processes or by urban activity, and can be transferred to the concrete matrix by either dry or wet deposition. Their ingress from the surface of concrete depends mainly on the porosity of the concrete matrix. It has been observed that the presence of sulphate can improve the resistance of concrete matrix to chloride ingress at an early exposure age but can increase chloride penetration at a later exposure. In addition, once the sulphates pollutants have reached the reinforcement, and in water presence, there is a $\mathrm{pH}$ reduction that accelerate corrosion processes [56. However, more studies are necessary in this field in order to understand the role of 
acidic compounds in chloride penetration and corrosion propagation processes.

\section{Corrosion due to chloride ingress}

Currently, the most significant and studied factor that induce corrosion of rebars is chloride presence [33, 57, 58, 59, 60, 61, 62. As we discuss above, behavior of chloride ions inside concrete are related to construction practices, environmental factors, and properties of the system. In this section we will address corrosion when cause specifically by the presence of chloride ions.

\subsection{Physical and chemical effects of chloride ingress on RC structures}

Chloride ions can be found in concrete in three forms: free, physically bound, and chemically bound. Free chlorides are mainly related to corrosion initiation. Physically bound or adsorbed chlorides, which are physically bounded by Van der Waals forces in the pores of C-S-H gel [63, 64, change the fibrous concrete structure decreasing the matrix porosity 65. Chemically bounded chlorides react with tricalcium aluminate to form Friedel's salts reducing the porosity and chloride diffusion rate in the structure [66, 62].

Chemical reactions that form Friedel's salts contribute more than physical interaction with C-S$\mathrm{H}$ to chloride binding capacity of concrete 67. Nevertheless, bound chlorides could be released by small changes in the environment $(\mathrm{pH}$, temperature, or carbonation) increasing corrosion initiation risks [68, 69, 70]. Chloride ingress might have also important physical effects on RC structures. For example, cracks appear as a result of salts crystallization inside the matrix, increasing the pore pressure. Additionally, because the saline solution penetrates and rises for capillarity, the attack is more intense when the RC is submerged in sea water or exposed to wet environments 52 .

\subsection{Critical chloride content}

Critical chloride content or chloride threshold is defined as the minimum quantity of total or free chlorides required to initiate rebar corrosion under optimal moisture, temperature, and oxygen [71. However, the determination of this critical chloride content is still nowadays a challenge. There are two definitions for the chloride threshold value [72, 32]:

(i) Definition 1: chloride threshold is related to the total or free chloride content required for depassivation of the steel (corrosion initiation). In this case, the critical chloride content will only depend on the chloride penetration process. 
(ii) Definition 2: chloride threshold is associated to acceptable deterioration of the structure (e.g., concrete cracking initiation). In this case, the chloride threshold will be also influenced by the corrosion propagation process.

Regarding the difficulty of distinguishing between free and bound chlorides, some researchers consider that this threshold value must be related the total chloride content [73, 74]. Authors, who consider that bound chlorides do not present any risk for corrosion initiation, have established that it can be determined as the ratio between free chlorides and weight of concrete [48. Other authors suggest that the best measure can be the critical chloride content capacity related to acid neutralization that represents the resistance to a fall in $\mathrm{pH}$ of the concrete [75, 76, 77.

Chloride threshold for corrosion initiation can be interpreted as the probability of corrosion related to free or total chloride content, or related to the ratio of chloride content/hydroxide concentration at the cover depth. Haussmann [78] studied the relationship between probability of corrosion and $\mathrm{Cl}^{-} / \mathrm{OH}^{-}$ratio and suggested a critical ratio of 0.6. This is, as suggested by the authors, only a lower bound; however, this value is not a clear threshold. Another measure is the ratio between the total chloride content to the cement content; for this measure, several thresholds have been found in the literature: $1.2 \%, 3 \%$, and $6 \%$ [37] and $0.316 \%$ [79]. Other indicators include: the ratio between total $\mathrm{Cl}^{-}$content by weight of cement, which suggest values of $1.24-3.08 \%$; if free $\mathrm{Cl}^{-}$concentration are used, the ratio values found range from $0.39-1.16 \%$. A final measure proposed is the $\mathrm{Cl}^{-} / \mathrm{OH}^{-}$ratio for which typical values range between 1.17-3.98 [80].

Recently, Alonso and Sanchez 34] wrote an overview of the variability of chloride threshold values found by different authors. They concluded that the method used to determine depassivation also influences the measurement of chloride threshold. A certain decay of corrosion potential $E_{\text {corr }}$ or an increase of corrosion rate $i_{\text {corr }}$ can be used as indicators of corrosion initiation. Alonso and Sanchez [34] classified testing methods for chloride threshold determination into two categories:

1. Accelerated methods: these methods are carried out in laboratory and take into account any external action that could affect the electrochemical conditions of the surface of the reinforcement from its natural state accelerating chloride penetration and/or corrosion initiation.

2. Natural methods: this category considers on-site tests or tests under natural exposure conditions. Therefore, the electrochemical changes occurring at the surface of the reinforcement during depassivation are not affected by any electrical action. 
Alonso and Sanchez [34] also reported that chloride thresholds can be affected by material parameters (cement composition, admixtures presence, etc.), environmental exposure (relative humidity, temperature, etc.) and concrete cracking. Therefore, they calculated different chloride threshold values depending on material and environmental characteristics. Table 1 presents in field results from exposure to natural chloride ingress. The column All measurements gathers measurements for all conditions (crack-uncracked, immersed-non-immersed); Crack + Air represents those measurements taken from cracked samples (crack size $>0.4 \mathrm{~mm}$ ) in splash and tidal zones; and Crack + Immersion are measurements that were taken from cracked samples (crack size $>0.4 \mathrm{~mm}$ ) immersed in seawater. It is clearly observed that the mean chloride threshold is lower for splash and tidal zones than immersed exposure. When all the measurements are gathered, the chloride threshold varies between the values for in air or immersed conditions with a very large coefficient of variation. If lifetime assessment or repair schedule are based on this information, corrosion initiation risks could be under or over estimated. Therefore, it is possible to conclude that the exposure conditions are paramount for the determination of a comprehensive chloride threshold.

\begin{tabular}{lccc}
\hline & All measurements & Crack + Air & Crack + Immersion \\
\hline Mean & 0.64 & 0.15 & 0.79 \\
Std. dev. (Coefficient of variation) & $0.61(0.95)$ & $0.06(0.40)$ & $0.39(0.49)$ \\
\hline
\end{tabular}

Table 1: Chloride threshold values at different exposure conditions (\%wt. of cement) 34

\subsection{Needs for chloride content measuring}

Preventive maintenance or RC structures subjected to chloride ingress could focus on diminishing corrosion initiation risks [32]. Therefore, measuring the evolution in time of chloride content would be useful for predicting, assessing, maintaining, and controlling lifetime, reliability, health and durability of RC structures. This information could be used among others to improve the understanding and modeling of the chloride ingress process, to determine a reliable chloride threshold for corrosion initiation, to characterize the uncertainties involved in the deterioration process, and to update deterioration models. Consequently, there is an agreement about the fact that an accurate and reliable technique for measuring chloride content into concrete structures is a mayor challenge that should be addressed urgently. 


\section{Overview of measurement techniques for chloride ingress}

Figure 3 shows the most common chloride content measurement techniques, which can be broadly classified as field and laboratory techniques. The most common are field destructive tests. These techniques take samples from in-service structures and determine chloride profiles by using chemical or physical lab techniques. Destructive techniques are mostly used for short term decisionmaking (e.g., repair and maintenance) but they can be used also for model updating [81, 32. However, some studies reported that there are significant differences between theoretical and measured chloride content profiles [82, 32. Errors in measurement can lead, for a given inspection, to underor over-estimations of the measured parameter that could conduct to wrong maintenance decisions.

An important group of lab techniques focus on characterizing the concrete before it is used in field. These techniques determine chloride diffusion coefficient that is used to predict the diffusion processes, and is useful for decision-making in the long run with more accurate information on the initial material. For this task, some researchers use Fick's law [83] or Nernst-Planck relation [84, 85]. However, others also use binding isotherms [62, moisture transport [33, and temperature variation 86. Table 2 gives conditions and parameters measured for each method, emphasizing the timewindow necessary for the decision-making. Although there are at least eleven methods available (Figure 3), only few of them are described by a normalized protocol. This fact clearly shows that chloride measuring assessment is still under development, and further studies are required.

Table 2 shows the objectives of each technique; in summary:

- Three of them aim to directly determine chloride concentration (Quantitative X-Ray diffraction analysis and Potentiometric evaluation for free chlorides and Volhard method for total chloride content).

- RCPT relates charge passed through a concrete slab to chloride penetrability in order to define the permeability of the material.

- Non steady state diffusion test and electrical migration test use diffusion models and complementary chemical techniques for characterizing the material.

- Impedance and ponding test accelerate diffusion processes for determining diffusion coefficient and chloride ingress profile. 


\begin{tabular}{|c|c|c|c|c|}
\hline Technique & General conditions & $\begin{array}{c}\text { Measured } \\
\text { parameters }\end{array}$ & $\begin{array}{c}\text { Complementary } \\
\text { techniques }\end{array}$ & Ref \\
\hline & \multicolumn{4}{|c|}{ Techniques for long time decision-making } \\
\hline $\begin{array}{c}\text { Rapid Chloride } \\
\text { Permeability Test, } \\
\text { RCPT }\end{array}$ & 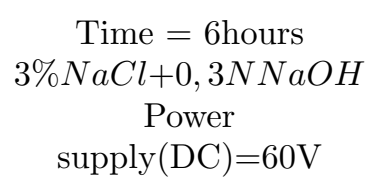 & $\begin{array}{c}\text { Charged passed. } \\
\text { Chloride } \\
\text { penetrability }\end{array}$ & & 87 \\
\hline $\begin{array}{l}\text { Non steady state } \\
\text { diffusion test }\end{array}$ & $\begin{array}{l}\text { Specimen cured for } \\
\text { 28days. } 2,8 \mathrm{M} \mathrm{NaCl} \text { for } \\
\text { 35days. } 0,5 \mathrm{~mm} \text { slice }\end{array}$ & $\begin{array}{l}\text { Fick's second } \\
\text { law. Diffusion } \\
\text { coefficient }\end{array}$ & Volhard method & 83 \\
\hline $\begin{array}{c}\text { Electrical Migration } \\
\text { Test }\end{array}$ & $\begin{array}{l}\text { Power supply } \\
(\mathrm{DC})=10-15 \mathrm{~V}\end{array}$ & $\begin{array}{l}\text { Diffusion } \\
\text { coefficient. } \\
\text { Ernst-Planck } \\
\text { equation }\end{array}$ & Volhard method & [88, 89] \\
\hline Impedance & $\begin{array}{c}\text { Specimens cured for } \\
24 \mathrm{~h} \text { at } 95 \% \mathrm{RH} . \\
\text { Electrode } \mathrm{KAg}(\mathrm{CN})_{2} \text {. } \\
\mathrm{NaOH}+\mathrm{NaCl} . \\
0,1 \mathrm{~Hz}-11,31 \mathrm{~Hz} . \text { Power } \\
\text { supply }(\mathrm{AC})=10 \mathrm{mV}\end{array}$ & $\begin{array}{l}\text { Diffusion } \\
\text { coefficient }\end{array}$ & & 29, 30, 31] \\
\hline \multirow[t]{2}{*}{ Ponding Test } & $\begin{array}{l}\text { Cured for } 14 \text { days. } \\
50 \% \mathrm{RH} 28 \text { days. } \\
3 \% \mathrm{NaCl} \text { for } 90 \text { days. } \\
12,7 \mathrm{~mm} \text { slice }\end{array}$ & $\begin{array}{l}\text { One- } \\
\text { dimensional } \\
\text { chloride ingress } \\
\text { profile }\end{array}$ & $\begin{array}{l}\text { Potentiometric } \\
\text { evaluation }\end{array}$ & 90 \\
\hline & \multicolumn{4}{|c|}{ Techniques for short time decision-making } \\
\hline $\begin{array}{l}\text { Quantitative X-Ray } \\
\text { Diffraction analysis }\end{array}$ & $\begin{array}{c}\text { Difractometer system. } \\
\text { Standard: } \mathrm{TiO}_{2}\end{array}$ & Free chloride & Volhard method & 91 \\
\hline Volhard method & $\begin{array}{c}\text { Dryed and powdered } \\
\text { sample. Titration } \\
\mathrm{NH}_{4} \mathrm{SCN}\end{array}$ & $\begin{array}{l}\text { Total chloride } \\
\text { content }\end{array}$ & & 92 \\
\hline $\begin{array}{c}\text { Potentiometric } \\
\text { evaluation }\end{array}$ & $\begin{array}{c}\text { Wet and powdered } \\
\text { sample. Titration } \\
\qquad \mathrm{NaNO}_{3}\end{array}$ & Free chloride & & 92 \\
\hline
\end{tabular}

Table 2: Common techniques for measuring chloride content in concrete structures 


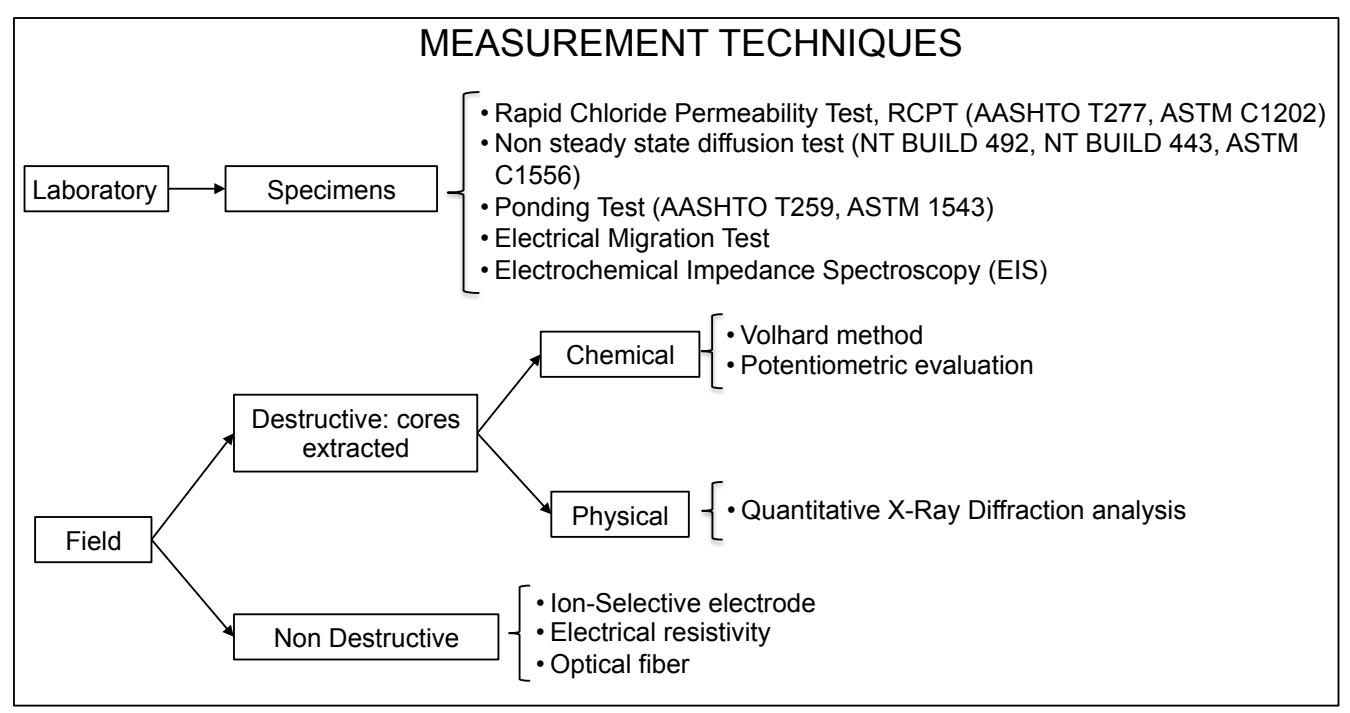

Figure 3: Common techniques for measuring chloride content and estimating diffusion coefficient in concrete structures

Summarizing, the chloride threshold determination method is still an open subject with a significant impact on defining maintenance policies.

\section{Non-destructive techniques (NDT)}

Over the past twenty years some NDTs: external techniques and embedded sensors have been developed for measuring chloride content in RC structures. The next subsections describe the main characteristics and discuss the advantages and drawbacks of the following methods:

1. Ion selective electrode (ISE)

2. Electrical resistivity (ER)

3. Optical fiber sensors (OFS)

There are specific NDT devices developed by different research groups for each method. For ISE and OFS all developed devices work in the same way while for ER techniques, the geometry, and experimental parameters are different.

\subsection{Ion selective electrode}

Ion Selective Electrode (ISE), also called potentiometric sensor, has been a useful technique in laboratory tests because it can determine free chloride, avoiding destructive and chemical tests 


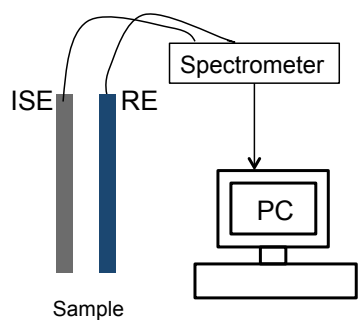

(a)

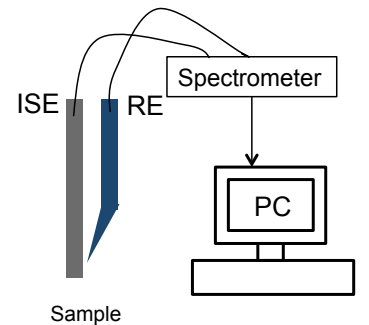

(b)

Figure 4: Techniques scheme based on ISE method (a) Normal RE and (b) RE with Luggin capillary

(pulverization and titration) 93. In field, this device is based on embedded sensors that could be used to determine free chloride concentration near the rebar without changing the environment surrounding [94]. ISE assesses the changes in potential difference that are related to the chemical activity and concentration of chloride ions, using Nernst equation:

$$
E=E^{0}+\frac{R T}{n F} \ln \left(a_{C l^{-}}\right)-E_{r e f}
$$

where $E$ is the measured voltage $[\mathrm{V}], E^{0}$ is the standard electrode potential (generally $\mathrm{Ag} / \mathrm{AgCl}$ ), $R$ is the gas constant $\left[\mathrm{J} \cdot \mathrm{mol}^{-1} \cdot \mathrm{K}^{-1}\right], T$ is the absolute temperature $[\mathrm{K}], n$ the number of electrons, $F$ is the Faraday constant $\left[C \cdot \mathrm{mol}^{-1}\right], a_{C l^{-}}$is the chemical activity of chloride ions $\left[\mathrm{mol} \cdot \mathrm{dm}^{-3}\right]$, and $E_{r e f}$ is the standard potential of the reference electrode $[\mathrm{V}]$.

To measure the electrical potential difference, it is necessary to complement the ISE with a reference electrode (RE) that is normally a calomel electrode [11, 10] (Figure 44). There are two geometrical arrays of RE, the first one (Figure $4 \mathrm{a}$ ) is an electrode situated several centimeters from the ISE, and the second one is a Luggin capillary (e.g., geometric shape of RE in Figure 4 4 ). The first geometric array can produce errors since the resistivity changes within the concrete matrix and may produce changes in the measurement [11]. On the other hand, Luggin capillary avoids this phenomenon due to its proximity to the ISE.

ISE has some advantages taking into account chemical and practical factors. For instance, it shows chemical stability in aggressive environments, its fabrication is easy through electrochemical processes, it can be adapted to other sensors for measuring other parameters (e.g. temperature, ions presence), and it has a known behavior due to its wide use in electrochemistry [12, 92. Nevertheless, 
there are factors that induce measurement errors and must be considered: temperature, alkalinity, electrical field presence and RE durability and prior calibration. Atkins et al. [12] stated that temperature can lead to measurement shifts. Vera et al. [15] demonstrated that high alkalinity of the pore solution can produce an interference in potentiometric response of an IES, especially at low chloride concentrations. Electrical field presence caused by corrosion processes, cathodic protection, chloride extraction, and other sensors produces shifts in potential difference measurements. Finally, as RE is necessary, it must show long term stability, but according to Elsener et al.[10] it is not possible under their experimental conditions. Besides, sometimes a prior calibration of reference electrodes is necessary. This calibration can change once the electrode is in the concrete because its alkalinity may affect the potential values [7, 13].

Currently, Duffó et al. [13, 14 made embedded electrodes that assess rebars' corrosion processes, temperature inside concrete, oxygen availability, and chloride content; this last one is measured with an $\mathrm{Ag} / \mathrm{AgCl}$ electrode. As they reported, these kind of sensors could be an inexpensive, accurate and promising technique for concrete durability assessment.

\subsection{Electrical resistivity}

Electrical resistivity (ER) has been related to RC corrosion [95, 96, 97, to the moisture and heat transfer in concrete [98, 99, 100] and, lately, to the presence of chloride ions [16, 18, 19, 101, 8]. This technique is related to chloride ingress because chloride presence can increase electrical current and reduce the resistivity of concrete [16, 18. Consequently, ER could be used to estimate chloride profiles by determining chloride diffusion coefficients. This method applies a voltage, measures the current flow and then computes electrical resistance that is proportional to electrical resistivity through Ohm's law:

$$
\begin{gathered}
V=I R, \\
R=\frac{A}{l} \rho
\end{gathered}
$$

where $V$ is the potential difference $[\mathrm{V}], I$ the electrical current $[\mathrm{A}], R$ the electrical resistance $[\Omega], A$ the surface through the current passes $\left[\mathrm{m}^{2}\right], l$ the length $[\mathrm{m}]$, and $\rho$ the electrical resistivity $[\Omega \cdot \mathrm{m}]$. The electrical resistivity is a unique characteristic and inherent for each material, and it depends on experimental conditions. 
In 1999 Gowers and Millard [96] made several recommendations about resistivity measurement technique for corrosion assessment using a Wenner array (Figure 5a); they were not intended for chloride measurement. Some of them were related to geometrical position, number of contact electrodes, space between them and distance from the rebar, to avoid measurement errors caused by surface contact area and electrical conductivity of the reinforcement. Other recommendations were made according to weather (temperature, relative humidity, and rainfall) and concrete composition (aggregates' size) that evidenced measurement disturbances. Also, they pointed out the importance of carbonation and chloride presences that increases or decreases resistivity, respectively. Consequently, carbonated surface or concrete with chlorides can produce wrong measurements. Finally, they did not recommend direct current (DC) because it produces errors in electrical potential measurements by electrode polarization.

Two years later, in 2001 Polder [16] studied another geometric array called disc technique (Figure 5b). According to Polder, even when the resistance can be converted to resistivity using a cell constant measured (depending on the cover depth and the rebar diameter), a precise calculation of the cell constant is not possible because the current flow cannot be predicted. In addition, the necessity to connect the rebar to the measurement system implies an invasive method of assessment. To calibrate the technique, Polder [16] and, some years later, McCarter and Vennesland [7] highlighted the necessity of a prior calibration and standardization of a reference material that must be the same studied material.

According to McCarter and Vennesland [7, resistivity not only depends on the geometry but also on the capillary connectivity, level of pore saturation, and concentration and mobility of ions in the pore solution. For those reasons, the assessment of the moisture content of concrete is very important to improve the effectiveness of the technique. Polder [16] suggested that the surface should be wetted by using wet sponges or wooden plugs to improve the electrical contact. Currently, Basheer et al. [18] and McPolin et al. [19] use another kind of device that has electrodes embedded into the concrete (Figure 5;), and each one has a part that is exposed to the concrete's environment. The measurement involves the same physical principle of Wenner or disc arrays (Equation 7), but in this case, the resistance is measured between pairs of electrodes. According to Basheer et al. [18, the measurements can be affected by alternative cementitious materials (ACM) presence that can change resistivity because of continued hydration. However, their results (apparent diffusion coefficient) are in agreement with those obtained by ponding test. 
ER methods are mainly used to determine the diffusion coefficient of concrete. For instance, McCarter et al. [101, 8] showed that Nernst-Einstein's equation relates the diffusion coefficient of a porous material $\left(D_{\text {eff }}\right)$, diffusion coefficient of chloride ions in the free electrolyte $\left(D_{0}\right)$, porosity $(\phi)$, tortuosity $(\tau)$, bulk electrical resistivity $(\rho)$, and resistivity of the interstitial pore fluid $\left(\rho_{0}\right)$ :

$$
\frac{D_{e f f}}{D_{0}}=\frac{\phi}{\tau}=\frac{\rho_{0}}{\rho}
$$

Lately, Loubser du Plooy [102] has proposed the multi-electrode resistivity (Figure 5d). This device is composed by two probes, one embedded and the other one mobile. The multi-electrode resistivity works as the Wener array technique does, and also needs moisture for improving the measurements. According to her results, this technique can be used for exploring the dependency of resistivity and chloride diffusivity on cement type and degree of hydration.

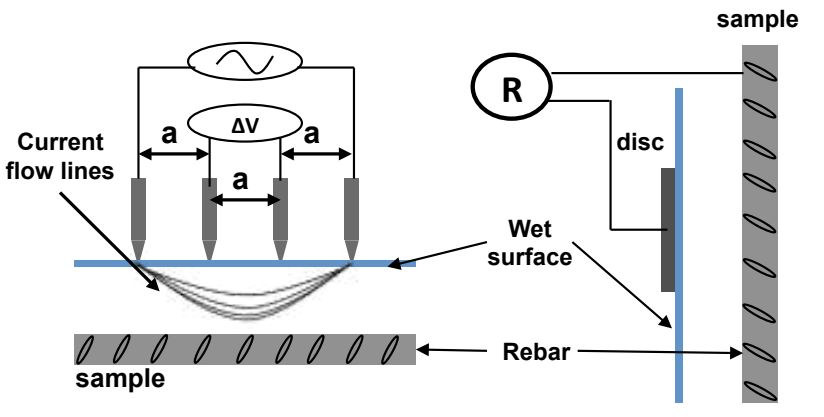

(a)

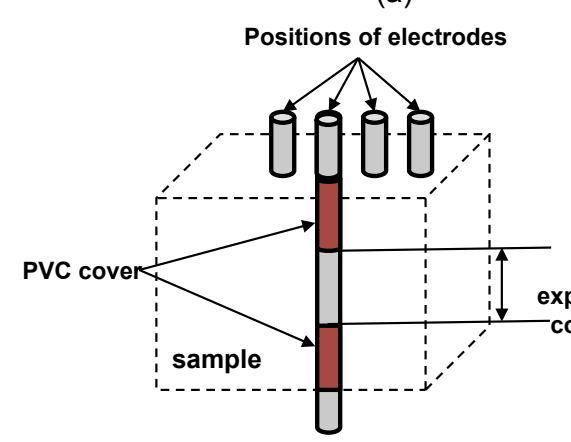

(c) (b)

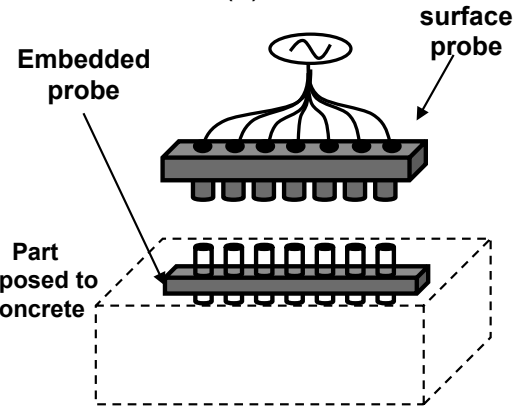

(d)

Figure 5: Techniques scheme based on ER method (a) Wenner array, (b) Disc, (c) Embedded electrodes, (d) Multielectrode resistivity probes. 
On the whole, after a comprehensive calibration, ER methods could be used to determine chloride diffusion coefficients. Nevertheless, they are very sensitive to the moisture content. For most of ER techniques the surface must be wet because the conductivity is zero for dry concrete. In addition, to ensure repeatability and accuracy, calibration relationships should be determined for different moisture levels. Measurements also depend on the geometry and the reinforcing configuration. Indeed, rebar presence and corners can modify measurements because these conditions modify the electrical field. There is not enough information about the durability of these devices in field. Consequently, more studies about durability of the devices based on ER are necessary.

\subsection{Optical fiber sensors}

In the past ten years some researchers have developed optical fiber sensors (OFS) for free chloride content assessment. This method involves detecting the refractive index shift due to the chloride presence that changes the light behavior that increases for larger chloride content [24, 23]. To make the measurement, the incident light can be ultraviolet [24] or laser 23]. The output light is studied by an optical spectrum analyzer (Figure 6) that gives the transmission spectra used to estimate the refractive index by [23]:

$$
\lambda_{m}=\left[n_{\text {core }}^{01}\left(n_{1}, n_{2}, \lambda_{m}\right)-n_{\text {clad }}^{0 m}\left(n_{2}, n_{s}, \lambda_{m}\right)\right] \Lambda
$$

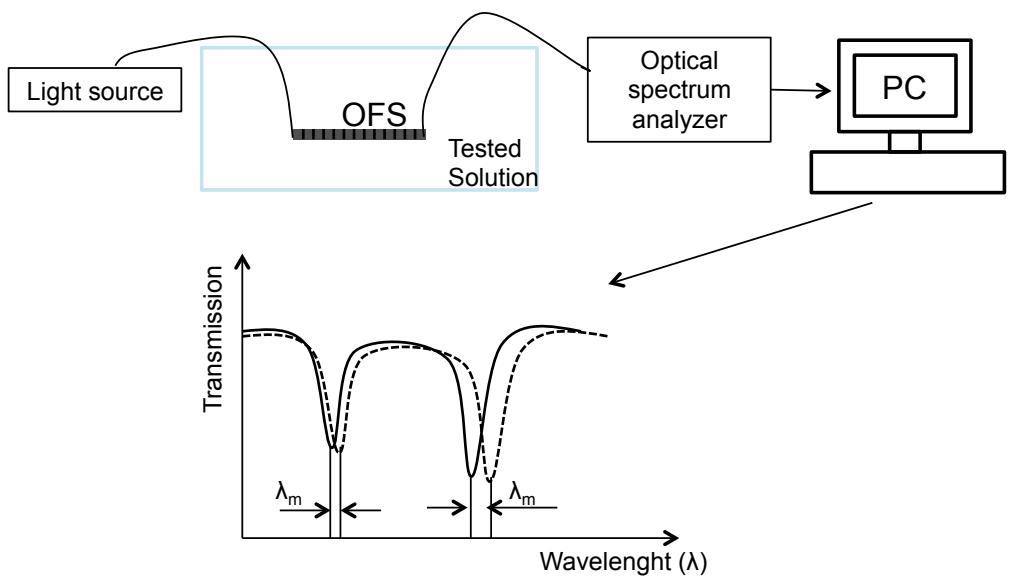

Figure 6: Optical fiber sensors scheme 
where $\lambda_{m}$ is the central wavelength that depends on the effective refractive index of the fundamental core mode $n_{\text {core }}^{01}\left(n_{1}, n_{2}, \lambda_{m}\right)$ and the effective refractive index of the $m^{\text {th }}$ cladding mode $n_{\text {clad }}^{0 m}\left(n_{2}, n_{s}, \lambda_{m}\right)$, where $n_{1}, n_{2}, n_{s}$ are the refractive indices of the core, the cladding, an the surrounding medium respectively, and $\Lambda$ is the grating period. When a change in the chloride concentration exists, refractive index changes in the surrounding medium, the cladding effective refractive index changes and, therefore a definite shift in the central wavelength, $\lambda_{m}$ (Figure 66 24, 23].

According to Lam et al. 24] and Tang et al. [23], the sensitivity of OFS can be improved using gold nanoparticles (gold colloids) that are deposited on the active grating surface of the OFS. For example, Tang et al. 23] found that lower limit of detection with and without gold colloids are $0.02 \mathrm{wt} \%$ (wt -weight solute x 100/weight solution) and 0.04wt\%, respectively. Similarly, Lam et al. 24 stated that the mean diameter of the gold particles affects the sensitivity. Particles of $16 \mathrm{~nm}$ provide a more sensitive device than $3 \mathrm{~nm}$ and $8 \mathrm{~nm}$ sizes.

OFS presents several advantages over other methods: it is energy saving, very sensitive to small chloride concentrations, and measures are not affected by electromagnetic fields [24, 103]. In addition, because of its geometry (long and thin) and its interaction capacity with the surrounding, the distribution of sensors is more convenient for large structural applications. This means, that since each segment of the fiber can act as a sensor, little perturbations anywhere in the structure can be detected [21].

However, OFS have some drawbacks that are important for a reliable and accurate measurement. For instance, optical fiber needs adequate protection to prevent its break during casting or service life. This protection must allow light transmission without obstructing or bending the optical fiber because the data can be missed [21]. Furthermore, OFS needs additional protection to isolate the fiber from corrosive environment and high temperatures [21] taking into account that temperature changes can affect the measurement, as Shu et al. [104] and Tang et al. have evidenced 23]. In their results, temperature variation $\left(0-120{ }^{\circ} \mathrm{C}\right)$ can vary the shift in peak wavelength from 1 to $7 \mathrm{~nm}$. Finally, until now, tests in concrete samples have not been reported. 


\subsection{Other promissory techniques}

There are other methods that are being studied for measuring chloride content in concrete structures; however, until now these studies are still developing, and although their results show direct influence of chloride content on acquired signals, they have not been enough for measuring chloride concentration in a precise and reliable way. Among these techniques Electrochemical Impedance Spectroscopy (EIS) and Grounding Penetrating Radar (GPR) are the most representative.

EIS is one of the most used electrochemical techniques [49]. It similarly works to ISE; however, EIS need three electrodes (Figure 7), while ISE just uses two of them (Figure 4). This technique works with a reference electrode (RE), a work electrode (WE), and an auxiliary electrode (AE). And it is based on measuring of impedance (real and imaginary) and phase angle while a constant voltage, and alternating current are applied; the analysis is done by equivalent circuits' modelling that resemble the response of the experiment, and give some parameters that can be related to physical phenomena that are occurring on the sample.

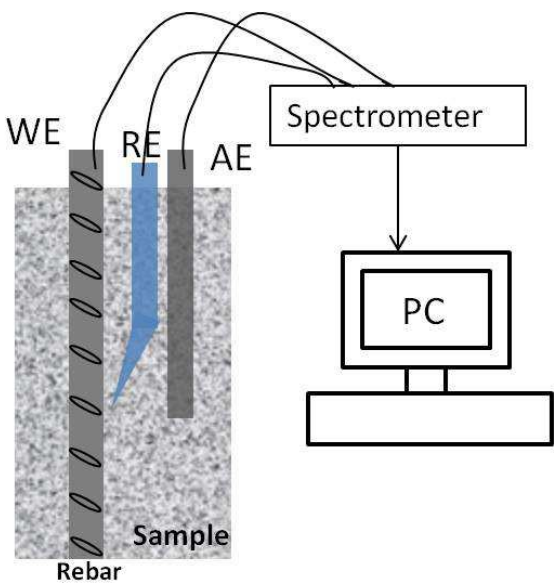

Figure 7: Electrochemical Impedance Spectroscopy scheme

This technique is non destructive and, in civil engineering field, it has bee used for determining corrosion type of rebar in-situ 13, 14, electrical impedance of the material (i.e. electrical resistance and capacitance) [14, 45, 105, behavior of the interfaces (e.g. concrete-reinforcement) [45, 106, microstructure changes due to degradation processes [45, 106, 107, and in chloride diffusion coefficient estimation in mortars samples in laboratory [29, 30, 31, as it is shown in Table 2

At late 90s several studies start to use EIS as sensor and biosensor for determining -in a non 
destructive way- corrosion, degradation processes, and inorganic ions in polymeric materials [27. In concrete structures, in 2008 and 2009 Vedalakshmi et al. [108, 109] estimated the diffusion coefficient of free chloride using EIS by analysing capacitive behavior of the system. Though they proposed it as a non-destructive and in-situ method for measuring chloride into concrete, other works in this field have not been found.

On the other hand, GPR is a widely used geophysical technique. In civil engineering GPR has been used for determining element thickness and locating metallic rebars, ducts, voids, honeycombs, delamination, cracking, and interfaces (e.g. asphalt-concrete) [25, 110, 111. This technique compares an incident electromagnetic wave to the reflected wave after its interaction with concrete and reinforcement (Figure 8). Incident wave is measured by detecting the direct wave, this wave interacts just with the concrete not with rebar, and reaches the receiving antenna, travelling smaller distance than reflected waves.

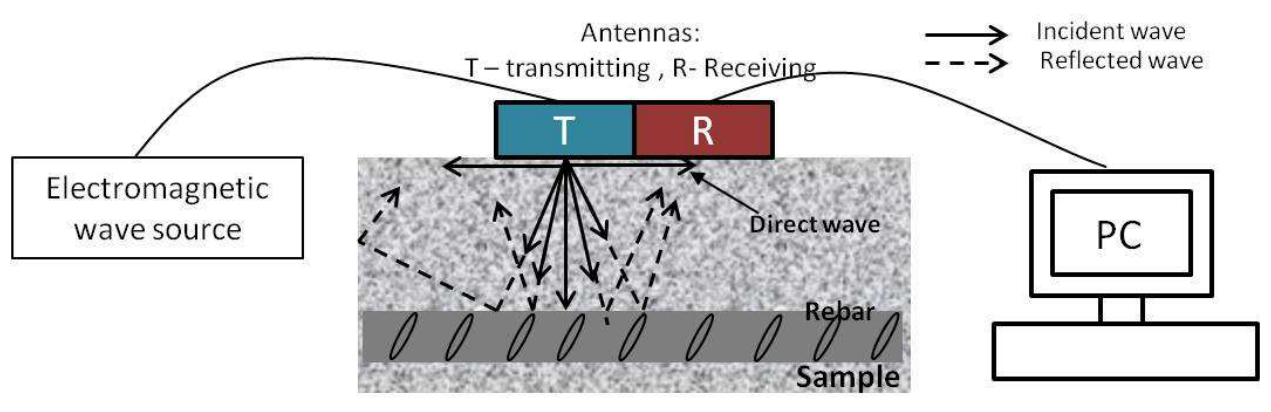

Figure 8: Grounding Penetrating Radar scheme

GPR shows highly dependence on geometric position, water presence, and chloride content. Geometric position influences the reflective wave since when corners or geometrical changes are present they behave as an interface between two different media, this phenomenon is known as border effects [112]. Water presence and chloride content affect wave signal in opposite ways, taking into account that reflection phenomena depends on wave velocity, and this depends on conductivity and capacitance. According to Soutsos et al. 25] humidity causes the reduction of relative permittivity and conductivity while chloride presence does not affect permittivity but increases conductivity of the material. However, Robert [113] determined that chloride ions do affect relative permittivity at low frequencies (less than 1GHZ). In addition, GPR repeatability depends on rebar depth (that cannot be controlled on site), and Sbartaï et al. [110] recommended 
to make the measure as far as possible from rebar.

Several works on GPR technique for measuring chloride content [25, 110, 112, 113, 114] agree on qualitative nature of the technique and the necessity of a mathematical model to numerically relate chloride concentration to GPR measurements. In 2009, Sbartaï et al. 115] proposed an artificial neural network (ANN) getting a good prediction accuracy (absolute error less than 1\% aprox.) but limited by specific material used for concrete mixture, geometry, and radar device used.

Finally, capacitive techniques have been little studied. In 1997, AL-Qadi et al. 28] detected total chlorides in concrete samples by using a parallel plate capacitor at low radio frequencies $(0.1 \mathrm{MHz}$ - 40.1MHz). This technique applies an alternating current and a constant voltage in a frequency range, measuring capacitive variation (complex and real permittivity). Figure 9 shows capacitive technique principle. Their results show that complex permittivity changes can be quantitatively related to chloride content at frequencies of $10 \mathrm{MHz}$. Nonetheless, they emphasized that water content and aggregates composition influence capacitance behavior of concrete. Recently, embedded capacitor sensor (ECS) for monitoring corrosion in rebar has been proposed [26] for durability assessment. According to their results, this capacitor has good performance: It can measure corrosion potential in specific point, and it is robust. Despite these results, it is necessary deeper studies.

Taking into account that for EIS, GPR, and capacitive methods there are not enough information, next comparison will be focused on ISE, ER and OFS.

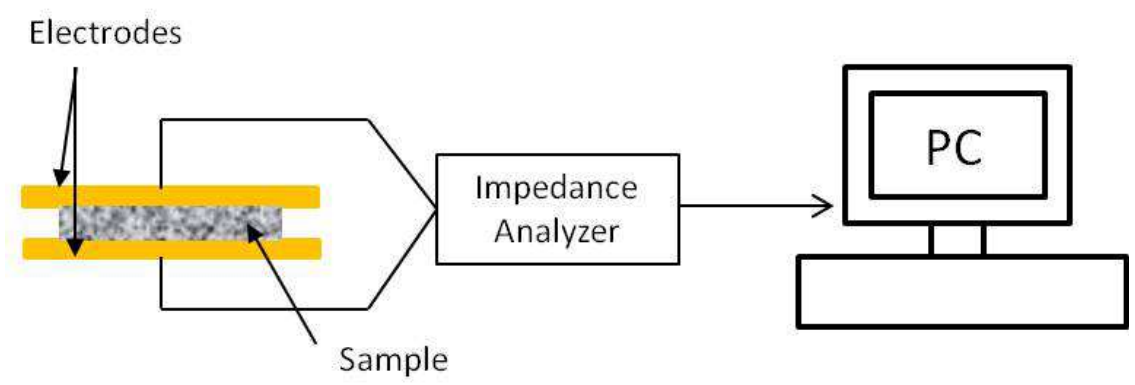

Figure 9: Parallel plate capacitor scheme

\section{Comparison among non destructive methods}

Since NDTs are based on different principles and are influenced by various parameters, the comparison among them will be based on the following performance characteristics: fabrication 
process, invasiveness, precision, and robustness (Table 3). Each method measures chloride ions or chloride diffusion coefficient, and depending on the chloride threshold used by technician/owner (Section 3.2), he/she must choose between free chloride and chloride diffusion coefficient. Also, depending on that chloride threshold it could be necessary to measure other kind of parameters (e.g. pH, humidity, other ions, etc.).

\begin{tabular}{|c|c|c|c|c|c|}
\hline & \multirow[t]{2}{*}{ ISE } & \multicolumn{3}{|c|}{ ER } & \multirow[t]{2}{*}{ OFS } \\
\hline & & Wenner/Disc & Electrodes & Multi-electrode & \\
\hline Operation & & \multirow{3}{*}{\multicolumn{3}{|c|}{$\begin{array}{c}\text { Electrical resistivity } \\
\mathrm{Cl}^{-} \text {diffusion coefficient }\end{array}$}} & \\
\hline Measured parameter & Chemical activity & & & & Index refraction \\
\hline Calculated parameter & Free $\mathrm{Cl}^{-}$ & & & & Free $\mathrm{Cl}^{-}$ \\
\hline \multicolumn{6}{|l|}{$\begin{array}{c}\text { Fabrication } \\
\text { process }\end{array}$} \\
\hline Previous knowledge & +++ & +++ & +++ & ++ & $+^{*}$ \\
\hline Ease & +++ & ++ & +++ & +++ & + \\
\hline Inexpensive & ++ & ++ & +++ & +++ & $-* *$ \\
\hline Less invasiveness & + & $+++/--$ & + & + & + \\
\hline \multicolumn{6}{|l|}{$\begin{array}{c}\text { Precision - } \\
\text { Accuracy }\end{array}$} \\
\hline Temperature & -- & -- & -- & -- & -- \\
\hline Moisture & -- & --- & --- & --- & -- \\
\hline Ions presence & - & -- & -- & -- & + \\
\hline Geometrical position & - & --- & N.I. & N.I. ${ }^{* * *}$ & +++ \\
\hline \multicolumn{6}{|l|}{ Robustness } \\
\hline Chemical stability & + & +++ & N.I. & N.I. & ++ \\
\hline Mechanical stability & + & +++ & N.I. & N.I. & + \\
\hline
\end{tabular}

* Somewhat good, ++ Good, +++ Quite good

** - Somewhat bad, -- Bad, - - - Quite bad

$* * *$ N.I. No information available

Table 3: Comparative analysis of NDT

Regarding operational differences, while ISE techniques measure chemical activity, ER assesses electrical resistivity and OFS the index refraction of the light inside the fiber. Likewise, they calculate different parameters: free chloride concentration for ISE and OFS, and chloride diffusion coefficient for ER techniques.

Fabrication process is very specific for each method. ISE are easily produced using electrochem- 
ical processes that are well known, predictable and cheaper than OFS. However, ISE may require some expensive materials (Ti, Ta, Ir) for improving durability of electrodes [14, 13]. ER devices already exist in the commerce because they have been mainly used in other fields (e.g. soil studies), but some parameters need to be determined (distance between electrodes, electrodes length) to enhance and optimize measurement accuracy. The construction of a OFS system is highly technical. Even if there are commercial optical fibers, golden nanoparticles must be produced in a laboratory, and as the required laser source could be expensive

Regarding invasiveness, in general, neither of the methods (ISE, ER, OFS) affect the structural behavior because sensors are small compared with the structural size. However, for ER methods, electrodes need space inside the concrete (Figure 55) and can touch the reinforcement (Figure 5 b). In contrast, ISE and OFS do not require any structural interference. However, most of these methods are embedded, and this fact do not make them destructive techniques since they do not change the environment surrounding during measuring.

Taking into account that ISE, OFS and some ER techniques are based on embedded systems, the robustness (the degree to which a system can function correctly in the presence of invalid inputs or stressful environmental conditions [116]), precision, accuracy and limit of detection (LOD) are relevant, and also they are strongly linked. Table 4 shows accuracy and LOD for ISE and OFS; however, concentration units used for each group are different and it is not possible to compare them without knowing other experimental conditions. In this aspect, accuracy is the measurement closeness to the real value (value given in percentage); precision is the measurement reproducibility, i.e., how close are measurement values taken several times under the same conditions [117] with protocols as described in [118; ; and LOD is, according to IUPAC, the ratio between sensor resolution and sensor sensitivity (value given in concentration) [119]. Note that combination of techniques is another opportunity to increase the detection capability [120, 121]

From the infrastructure managers' point of view, two goals are aimed: (1) the comparison of the total chloride content to a target near the rebar and (2) the free/total chloride profile for model updating and residual service life-time prediction from inspection. When considering the first one a wide range of chloride threshold are available in the literature depending on the concrete composition, the exposure, etc. Let us consider NF EN 206-1 which suggests the limit content of $0.4 \%$ of chloride ions weight by cement weight [122]. An accuracy of $10 \%\left(0.04 \% \mathrm{Cl}^{-}\right.$weight/cement weight) of this value is required for limitation of non detections and false alarms. Detailed informa- 
tion about the relationship between inspection quality and maintenance is available in Sheils et al. [123. For the second target, actual works are still in progress. The aim is to detect the maximum value of a chloride profile. For aged structures in an atmospheric zone, the maximum value in the data base of University of Nantes is $0.8 \% \mathrm{Cl}^{-}$weight / cement weight. If ten points are required for representing the decreasing part of the profile from this maximum value to 0 , the accuracy should be at least one-tenth of one interval: $0.08 \% \mathrm{Cl}^{-}$weight/cement weight. From these two targets value, the target order of magnitude for the accuracy is about $10^{-2} \% \mathrm{Cl}^{-}$weight/cement weight.

Thus, any system should be robust, precise and accurate with respect to the following aspects:

- the measurements are independent of changes in relative humidity inside the concrete;

- the measurements do not change if the sensor is subjected to temperature of $\mathrm{pH}$ variations or mechanical stresses (normally presented during the curing process and during structural life-time); or

- the measurements are not influenced by changes resulting of reactions with sulphates and other chemical species within concrete.

\begin{tabular}{c|c|c|c}
\hline & ISE & ER & OFS \\
& {$[10,12,15]$} & {$[8,19,17]$} & {$[23]$} \\
\hline \multirow{3}{*}{ Accuracy } & $\begin{array}{c}\text { Strongly } \\
\text { depends on } \\
\text { temperature }\end{array}$ & $\begin{array}{c}\text { Strongly depends } \\
\text { on temperature, humidity, } \\
\text { and ions presence }\end{array}$ & $\begin{array}{c}\text { W/ nanoparticles } 0.2 \% \\
\text { W/o nanoparticles } 0.6 \%\end{array}$ \\
\hline \multirow{4}{*}{ LOD } & $\mathrm{pH},\left[\mathrm{Cl}^{-}\right]^{* *}$ & & \\
& $12.3,2 \times 10^{-4}$ & & W/ nanoparticles $0.02 \mathrm{wt} \%$ \\
& $12.9,7 \times 10^{-4}$ & N.I. & W/o nanoparticles $0.04 \mathrm{wt} \%$ \\
& $13.4,2 \times 10^{-3}$ & & \\
\hline
\end{tabular}

*N.I. No information available

$* * \operatorname{Molality}(m)=\operatorname{solute}($ moles $) / \operatorname{solvent}(\mathrm{kg})$

Table 4: Measurement quality standards for ISE, ER and OFS

The key aspect that influences all measurements methods (ISE, ER or OFS) is temperature 23, 20, 12, 10, 96, 16. ER is also highly dependent on moisture content, temperature and ions presence, as Table 4 shows. ISE devices can generally resist aggressive environments, but important 
parameters, such as LOD, depend on environmental $\mathrm{pH}$. In addition, the reference electrode, that is essential for their optimal performance, is less resistant than the other parts of the device. On the other hand, ER (Wenner and disc techniques) do not need special care because the embedded parts are generally built in stainless steel and other parts are not permanently placed in the concrete nor exposed to environment. The OFS method requires extra protection for isolating optical fibers from water, temperature, and concrete alkalinity. Since optical fibers are placed in the concrete mix during casting they should be protected against breaking and bending. ISE is less robust concerning chemical reactions and mechanical actions.

The criteria of durability is clearly an essential component of any of these techniques. However, no reports on this aspects have been found in the literature.

\section{Challenges for the development/improvement of NDT devices}

On the basis of previous literature review and discussions, it is possible to identify the following challenges for future research on chloride measurement by using NDTs:

1. Independence of environmental actions: the measurements under specific conditions for temperature, moisture content, $\mathrm{pH}$, and/or the presence of sulphates or $\mathrm{CO}_{2}$ may produce errors that should be carefully controlled. The first challenge of NDTs is then to develop sensors that avoid or compensate environmental conditions effects.

2. Independence of geometry: the presence of rebars, corners, or electrical fields in RC structures can distort electrical or electrochemical signals, causing underestimation/overestimation of the measurements. New measurement techniques should be capable to take data from concrete structures regardless of the geometrical configuration of the structural component nor the layout of the reinforcement.

3. Multi-measurement ability: NDTs should be developed or combined with other NDTs to assess more parameters that induce errors in the measurement of chloride concentrations, this can help to better understand the interactions and therefore to obtain measures independent of specific conditions. For example, the assessment of carbonation reaction is important taking into consideration that it can produce $\mathrm{pH}$ fall, porosity changes, and corrosion acceleration [124]. At the end, it is probable that this reaction interferes on NDT's chloride concentration measurements, as well as other important parameters: sulphate presence, $\mathrm{pH}$, temperature and moisture content. 
4. Chemical stability, durability and maintainability: most structures are planned for lifetimes between 50 and 100 years. Thus, NDTs should be able of withstanding chemical changes inside the concrete matrix and to be operational or easily replaceable during the structural lifetime.

5. Costs: it is necessary to develop measuring methods that are not expensive in terms of costs of construction, installation and maintenance during the structural lifetime.

\section{Conclusions}

Chloride ingress is one of the major problems for concrete durability. Free chlorides lead corrosion processes, while bounded chlorides can be released and become free chlorides. To determine repairing times, some techniques have been developed; however, most of them are destructive and invasive. In the last 20 years, some studies have used some non-destructive an in-situ methods for developing several NDT that have shown good possibilities for measuring, controlling, or modeling chloride ingress in concretes. These methods are: Ion electrode selective, Electrical resistivity, and Optical fiber sensors.

Ion electrode selective method has been applied in concretes because it has been studied in electrochemistry for several years, the knowledge about the method is wide, and it is capable to distinguish chloride ions from other ions. Some results suggest that this method generates accurate measurements. However, geometrical position, alkalinity and temperature can change measurements. In addition, durability of reference electrode must be taken into account. Likewise, Electrical resistivity, which has been used in soil studies, is a useful method for chloride measuring. Some techniques based on this method do not need to be embedded, and they can take measurements from outside in a non-invasive way. Nevertheless, humidity degree of the concrete surface, distance to the rebar, carbonation presence, and electrical fields change measurements. In addition, prior calibration of the concrete must be done. Additionally, optical fiber sensors are the most promissory technique. They are not affected by environmental factors, geometrical distribution, ions presences or electromagnetic fields. Nevertheless, the fiber needs an extra protection to isolate it from corrosive environment and protect it during concreting.

Although other NDTs have been proposed such as electrochemical impedances spectroscopy, grounding penetrating radar and capacitive methods, until now, there is not enough results about their performance, accuracy, robustness, chemical stability, etc. 
Owners and managers are waiting for cheap and reliable NDT measurements for corrosion initiation risk assessment and maintenance optimization, especially for preventive maintenance. In concrete structures, corrosion processes not only depend on chloride presence but also on other conditions (e.g. humidity, temperature, $\mathrm{pH}$, carbonation, etc.) that also influence the reliability of NDT measurements. Consequently, research efforts should focus on the improvement of the accuracy of these NDTs under in-field exposure conditions.

\section{Acknowledgements}

The authors would like to acknowledge the financial support of Departamento Administrativo de Ciencia, Tecnología e Innovación - Colciencias conv. 528 - 2011.

\section{References}

[1] F. Glasser, J. Marchand, E. Samson, Durability of concrete - degradation phenomena involving detrimental chemical reactions, Cement and Concrete Research 38 (2) (2008) 226-246, 12th International Congress on the Chemistry of Cement. Montreal, Canada, July 8-13 2007. URL http://www.sciencedirect.com/science/article/pii/S0008884607002190

[2] C. Andrade, M. Castellote, R. d'Andrea, Measurement of ageing effect on chloride diffusion coefficients in cementitious matrices, Journal of Nuclear Materials 412 (1) (2011) 209-216. URL http://www.sciencedirect.com/science/article/pii/S002231151001072X

[3] M. Salta, E. Pereira, Factors influencing the corrosion in reinforced concrete. State of the art. Report $\mathrm{N}^{\circ}$ 2-3 Concrete in marine environment, Tech. rep., Laboratório Nacional de Engenharia Civil, LNEC (2000-2006).

[4] G. Koch, M. Brongers, N. Thompson, Y. Virmani, J. Payer, Corrosion costs and preventive strategies in the United States, Tech. rep., U.S. Department of tranportation Federal Highway Administration, CC Technologies Laboratories, Inc. and NACE international (2002).

URL http://www .nace.org/uploadedFiles/Publications/ccsupp.pdf

[5] X. Shi, N. Xie, K. Fortune, J. Gong, Durability of steel reinforced concrete in chloride environments: An overview, Construction and Building Materials 30 (0) (2012) 125-138.

URL http://www.sciencedirect.com/science/article/pii/S095006181100715X 
[6] DURATINET - project context, http://www.duratinet.org/ (2012).

URL http://www.duratinet.org/

[7] W. J. McCarter, O. Vennesland, Sensor systems for use in reinforced concrete structures, Construction and Building Materials 18 (2004) 351-358.

URL http://www.sciencedirect.com/science/article/pii/S0950061804000443

[8] M. McCarter, T. M. Chrisp, G. Starrs, A. Adamson, E. Owens, P. Basheer, S. Nanukuttan, S. Srinivasan, N. Holmes, Developments in performance monitoring of concrete exposed to extreme environments, Journal of infrastructure systems ASCE 18 (2012) 167-175.

URL http://dx.doi.org/10.1061/(ASCE) IS.1943-555X.0000089

[9] R. Prakash, Non-destructive testing techniques, New Age Science, 2009.

[10] B. Elsener, L. Zimmermann, H. Böhni, Non destructive determination of the free chloride content in cement based materials, Materials and Corrosion 54 (6) (2003) 440-446.

URL http://dx.doi.org/10.1002/maco.200390095

[11] C. Atkins, J. Scantlebury, P. Nedwell, S. Blatch, Monitoring chloride concentrations in hardened cement pastes using ion selective electrodes, Cement and Concrete Research 26 (2) (1996) 319-324.

URL http://www.sciencedirect.com/science/article/pii/0008884695002189

[12] C. Atkins, M. Carter, J. Scantlebury, Sources of error in using silver/silver chloride electrodes to monitor chloride activity in concrete, Cement and Concrete Research 31 (8) (2001) 12071211.

URL http://www.sciencedirect.com/science/article/pii/S0008884601005440

[13] G. Duffó, S. Farina, C. Giordano, Characterization of solid embeddable reference electrodes for corrosion monitoring in reinforced concrete structures, Electrochimica Acta 54 (3) (2009) $1010-1020$.

URL http://wWw.sciencedirect.com/science/article/pii/S001346860801013X

[14] G. Duffó, S. Farina, Development of an embeddable sensor to monitor the corrosion process of new and existing reinforced concrete structures, Construction and Building Materials 23 
(2009) 2746-2751.

URL http://www.sciencedirect.com/science/article/pii/S0950061809001123

[15] G. de Vera, M. Climent, C. Antón, A. Hidalgo, C. Andrade, Determination of the selectivity coefficient of a chloride ion selective electrode in alkaline media simulating the cement paste pore solution, Journal of Electroanalytical Chemistry 639 (2010) 43-49.

URL http://www.sciencedirect.com/science/article/pii/S0022072809004276

[16] R. Polder, Test methods for on site measurement of resistivity of concrete - a RILEM TC-154 technical recommendation, Construction and Building Materials 15 (2001) 125-131.

URL http://www.sciencedirect.com/science/article/pii/S0950061800000611

[17] R. Polder, W. Peelen, Characterisation of chloride transport and reinforcement corrosion in concrete under cyclic wetting and drying by electrical resistivity, Cement and Concrete Composites 24 (2002) 427-435.

URL http://www.sciencedirect.com/science/article/pii/S0958946501000749

[18] P. Basheer, P. Gilleece, A. Long, W. J. M. Carter, Monitoring electrical resistance of concretes containing alternative cementitious materials to assess their resistance to chloride penetration, Cement and Concrete Composites 24 (2002) 437-449.

URL http://www.sciencedirect.com/science/article/pii/S0958946501000750

[19] D. McPolin, P. Basheer, A. Long, K. Grattan, T. Sun, Obtaining progressive chloride profiles in cementitious materials, Construction and Building Materials 19 (9) (2005) 666-673.

URL http://www.sciencedirect.com/science/article/pii/S0950061805001297

[20] S. James, R. Tatam, Optical fibre long-period grating: characteristic and application, Measurement science and technology 14 (2003) R49-R61.

URL http://bit.1y/1oSCbWw

[21] H. Li, D.-S. Li, G.-B. Song, Recent applications of fiber optic sensors to health monitoring in civil engineering, Engineering Structures 26 (2004) 1647-1657.

URL http://www.sciencedirect.com/science/article/pii/S014102960400183X

[22] O. S. Wolfbeis, Fiber-optic chemical sensors and biosensors, Analytical Chemistry 76 (2004) 
$3269-3284$.

URL http://pubs .acs.org/doi/abs/10.1021/ac303159b

[23] J.-L. Tang, J.-N. Wang, Measurement of chloride-ion concentration with long-period grating technology, Smart materials and structures 16 (2007) 665-672.

URL http://iopscience.iop.org/0964-1726/16/3/013

[24] C. Lam, R. Mandamparambil, T. Sun, K. Grattan, S. Nanukuttan, S. Taylor, P. Basheer, Optical fiber refractive index sensor for chloride ion monitoring, Sensors Journal, IEEE 9 (2009) 525-532.

[25] M. Soutsos, J. Bungey, S. Millard, M. Shaw, A. Patterson, Dielectric properties of concrete and their influence on radar testing, NDT \& E International 34 (6) (2001) 419-425.

URL http://www.sciencedirect.com/science/article/pii/S0963869501000093

[26] S. F. Abdul Rahman, M. Ismail, N. Norhazilan, H. Bakhtiar, Embedded capacitor sensor for monitoring corrosion of reinforcement in concrete, Journal of Engineering Science and Technology 7 (2) (2012) 209-218.

URL http://jestec.taylors.edu.my/Vol\%207\%20Issue $\% 202 \% 20$ April $\% 2012 /$ Vol_7_2_ 209_218_SITI\%20FATIMAH\%2OABDUL\%20RAHMAN.pdf

[27] C. Fernández-Sánchez, C. J. McNeil, K. Rawson, Electrochemical impedance spectroscopy studies of polymer degradation: application to biosensor development, TrAC Trends in Analytical Chemistry 24 (1) (2005) 37-48.

URL http://www.sciencedirect.com/science/article/pii/S0165993604030572

[28] I. Al-Qadi, R. Haddad, S. Riad, Detection of chlorides in concrete using low radio frequencies, Journal of Materials in Civil Engineering 9 (1) (1997) 29-34.

URL http://ascelibrary.org/doi/abs/10.1061/\%28ASCE $\% 290899-1561 \% 281997 \% 299 \%$ $3 \mathrm{~A} 1 \% 2829 \% 29$

[29] M. Shi, Z. Chen, J. Sun, Determination of chloride diffusivity in concrete by AC impedance spectroscopy, Cement and Concrete Research 29 (1999) 1111-1115.

URL http://www.sciencedirect.com/science/article/pii/S0008884699000794 
[30] B. Díaz, X. R. Nóvoa, M. C. Pérez, Study of the chloride diffusion in mortar: A new method of determining diffusion coefficients based on impedance measurements, Cement and Concrete Composites 28 (2006) 237-245.

URL http://www.sciencedirect.com/science/article/pii/S0958946506000163

[31] J. Deus, B. Díaz, L. Freire, X. Nóvoa, The electrochemical behaviour of steel rebars in concrete: an electrochemical impedance spectroscopy study of the effect of temperature, Electrochimica Acta 131 (2014) 106-115.

URL http://www.sciencedirect.com/science/article/pii/S0013468613024481

[32] E. Bastidas-Arteaga, F. Schoefs, Stochastic improvement of inspection and maintenance of corroding reinforced concrete structures placed in unsaturated environments, Engineering Structures 41 (2012) 50-62.

URL http://www.sciencedirect.com/science/article/pii/S0141029612001290

[33] B. Oh, S. Jang, Effects of material and environmental parameters on chloride penetration profiles in concrete structures, Cement and Concrete Research 37 (2007) 47-53.

URL http://www.sciencedirect.com/science/article/pii/S000888460600216X

[34] M. Alonso, M. Sanchez, Analysis of the variability of chloride threshold values in the literature, Materials and Corrosion 60 (8) (2009) 631-637.

URL http://dx.doi .org/10.1002/maco.200905296

[35] M. Sánchez-Silva, G.-A. Klutke, D. V. Rosowsky, Life-cycle performance of structures subject to multiple deterioration mechanisms, Structural Safety 33 (2011) 206-217.

URL http://www.sciencedirect.com/science/article/pii/S0167473011000105

[36] J. Olaya-Flórez, M. Torres-Luque, Resistencia a la corrosión de recubrimientos orgánicos por medio de espectrosopia de impedancia electroquímica, Revista Ingeniería y Universidad 16 (2012) 43-58.

URL http://www .redalyc.org/articulo.oa?id=47723297003

[37] J. Broomfield, Corrosion of steel in concrete, 2nd Edition, Taylor \& Francis, 2007, Ch. Understanding, investigation and repair. 
[38] A. Neville, Chloride attack of reinforced concrete: An overview, Materials and Structures 28 (1995) 63-70.

URL http://dx.doi.org/10.1007/BF02473172

[39] J. Galvele, Tafel's law in pitting corrosion and crevice corrosion susceptibility, Corrosion Science 47 (2005) 3053-3067.

URL http://www.sciencedirect.com/science/article/pii/S0010938X05002234

[40] B. Pradhan, B. Bhattacharjee, Rebar corrosion in chloride environment, Construction and Building Materials 25 (2011) 2565-2575.

URL http://www.sciencedirect.com/science/article/pii/S095006181000629X

[41] R. Vera, M. Villarroel, A. Carvajal, E. Vera, C. Ortiz, Corrosion products of reinforcement in concrete in marine and industrial environments, Materials Chemistry and Physics 114 (1) (2009) 467-474.

URL http://www.sciencedirect.com/science/article/pii/S0254058408007839

[42] C. Jaegermann, Effect of water-cement ratio and curing on chloride penetration into concrete exposed to mediterranean sea climate, ACI Materials Journal 87 (1990) 333-339.

[43] S. Ahmad, Reinforcement corrosion in concrete structures, its monitoring and service life prediction- A review, Cement and Concrete Composites 25 (2003) 459-471.

URL http://www.sciencedirect.com/science/article/pii/S0958946502000860

[44] Rasheeduzzafar, S. E. Hussain, S. Al-Saadoun, Effect of cement composition on chloride binding and corrosion of reinforcing steel in concrete, Cement and Concrete Research 21 (5) (1991) $777-794$.

URL http://www.sciencedirect.com/science/article/pii/000888469190173F

[45] D. A. Koleva, K. van Breugel, J. H. W. de Wit, E. van Westing, O. Copuroglu, L. Veleva, A. Fraaij, Correlation of microstructure, electrical properties and electrochemical phenomena in reinforced mortar. breakdown to multi-phase interface structures. Part I: Microstructural observations and electrical properties, Materials Characterization 59 (2008) 290-300.

URL http://wWw.sciencedirect.com/science/article/pii/S1044580307000332 
[46] T. Mohammed, N. Otsuki, M. Hisada, Corrosion of steel bars with respect to orientation in concrete, ACI Materials Journal 96 (1999) 154-159.

URL http://bit.1y/1wBE3aR

[47] T. Mohammed, N. Otsuki, M. Hisada, T. Shibata, Effect of crack width and bar types on corrosion of steel in concrete, Journal of materials in Civil Engineering ASCE 13 (2001) 194201.

URL http://dx.doi.org/10.1061/(ASCE)0899-1561(2001)13:3(194))

[48] T. Mohammed, H. Hamada, Corrosion of steel bars in concrete with various steel surface conditions, ACI Materials Journal 103 (2006) 233-242.

[49] M. Torres-Luque, Estudio comparativo del proceso de corrosión en recubrimientos cerámicos, metálicos y orgánicos mediante técnicas electroquímicas, Master's thesis, Universidad Nacional de Colombia (2010).

URL http://bit.ly/RMfneU

[50] L. Mammoliti, C. Brown, C. M. Hansson, B. B. Hope, The influence of surface finish of reinforcing steel and ph of the test solution on the chloride threshold concentration for corrosion initiation in synthetic pore solutions, Cement and Concrete research 26 (1996) 545-550.

URL http://www.sciencedirect.com/science/article/pii/000888469600018X

[51] E. Bastidas-Arteaga, A. Chateauneuf, M. Sánchez-Silva, P. Bressolette, F. Schoefs, Influence of weather and global warming in chloride ingress into concrete: A stochastic approach, Structural Safety 32 (2010) 238-249.

URL http://www.sciencedirect.com/science/article/pii/S0167473010000214

[52] S. Erdogdu, I. Kondratova, T. Bremner, Determination of chloride diffusion coefficient of concrete using open-circuit potential measurements, Cement and Concrete Research 34 (2004) 603-609.

URL http://www.sciencedirect.com/science/article/pii/S0008884603003624

[53] A. Costa, J. Appleton, Chloride penetration into concrete in marine environment - Part I: Main parameters affecting chloride penetration, Matériaux et constructions 32 (1999) 252259.

URL http://link.springer.com/article/10.1007/BF02479594 
[54] V. Zivica, A. Bajza, Acidic attack of cement based materials - A review.: Part 1. principle of acidic attack, Construction and Building Materials 15 (8) (2001) 331-340.

URL http://www.sciencedirect.com/science/article/pii/S0950061801000125

[55] N. Marinoni, M. P. Birelli, C. Rostagno, A. Pavese, The effects of atmospheric multipollutants on modern concrete, Atmospheric Environment 37 (33) (2003) 4701-4712.

URL http://www.sciencedirect.com/science/article/pii/S1352231003006265

[56] J. Zuquan, S. Wei, Z. Yunsheng, J. Jinyang, L. Jianzhong, Interaction between sulfate and chloride solution attack of concretes with and without fly ash, Cement and Concrete Research 37 (8) (2007) 1223-1232.

URL http://www.sciencedirect.com/science/article/pii/S000888460700052X

[57] C. Andrade, M. Keddam, X. R. Nóvoa, M. C. Pérez, C. M. Rangel, H. Takenouti, Electrochemical behaviour of steel rebars in concrete: influence of environmental factors and cement chemistry, Electrochimica Acta 46 (2001) 3905-3912.

URL http://www.sciencedirect.com/science/article/pii/S0013468601006788

[58] M. Lorenzo, S. Goñi, A. Guerrero, Role of aluminous component of fly ash on the durability of portland cement-fly ash pastes in marine environment, Waste Management 23 (8) (2003) $785-792$.

URL http://www.sciencedirect.com/science/article/pii/S0956053X03000308

[59] C. Arya, N. Buenfeld, J. Newman, Factors influencing chloride-binding in concrete, Cement and Concrete Research 20 (2) (1990) 291-300.

URL http://www.sciencedirect.com/science/article/pii/000888469090083A

[60] O. T. de Rincón, M. Sánchez, V. Millano, R. Fernández, E. A. de Partidas, C. Andrade, et al., Effect of the marine environment on reinforced concrete durability in iberoamerican countries: DURACON project/CYTED, Corrosion Science 49 (2007) 2832-2843.

URL http://www.sciencedirect.com/science/article/pii/S0010938X07000327

[61] G. R. Meira, C. Andrade, C. Alonso, J. J. Borba, M. J. Padilha, Durability of concrete structures in marine atmosphere zones - the use of chloride deposition rate on the wet candle as an environmental indicator, Cement and Concrete Composites 32 (2010) 427-435.

URL http://www.sciencedirect.com/science/article/pii/S0958946510000399 
[62] Q. Yuan, C. Shi, G. D. Schutter, K. Audenaert, D. Deng, Chloride binding of cement-based materials subjected to external chloride environment - A review, Construction and Building Materials 23 (1) (2009) 1-13.

URL http://www.sciencedirect.com/science/article/pii/S095006180800055X

[63] T. Zhang, O. E. Gjørv, Diffusion behavior of chloride ions in concrete, Cement and Concrete Research 26 (1996) 907-917.

URL http://www.sciencedirect.com/science/article/pii/0008884696000695

[64] A. V. Saetta, R. Scotta, R. Vitaliani, Analysis of chloride diffusion into partially saturated concrete, ACI Materials Journal 90 (1993) 441-451.

[65] A. K. Suryavanshi, J. D. Scantlebury, S. B. Lyon, Pore size distribution of OPC \& SRPC mortars in presence of chlorides, Cement and Concrete Research 25 (1995) 980-988.

URL http://www.sciencedirect.com/science/article/pii/000888469500093R

[66] B. Martín-Pérez, H. Zibara, R. D. Hooton, M. D. A. Thomas, A study of the effect of chloride binding on service life predictions, Cement and Concrete Research 30 (8) (2000) 1215-1223. URL http://www.sciencedirect.com/science/article/pii/S0008884600003392

[67] Y. Hosokawa, K. Yamada, B. Johannesson, L.-O. Nilsson, Models for chloride ion bindings in hardened cement paste using thermodynamic equilibrium calculations, in: J. Marchand, B. Bissonnette, R. Gagné, M. Jolin, F. Paradis (Eds.), 2nd Interantional RILEM Symposium on Advances in Concrete through Science and Engineering, 2006.

URL http://bit.1y/1kqyEJT

[68] G. Glass, N. Buenfeld, The influence of chloride binding on the chloride induced corrosion risk in reinforced concrete, Corrosion Science 42 (2) (2000) 329-344.

URL http://www.sciencedirect.com/science/article/pii/S0010938X99000839

[69] B. Reddy, G. K. Glass, P. J. Lim, N. R. Buenfeld, On the corrosion risk presented by chloride bound in concrete, Cement and Concrete Composites 24 (2002) 1-5.

URL http://www.sciencedirect.com/science/article/pii/S095894650100021X

[70] H. Zibara, Binding of external chlorides by cement pastes, Ph.D. thesis, University of Toronto (2001). 
[71] H. Cook, W. McCoy, Influence of chloride in reinforced concrete, American Society for Testing and Materials ASTM STP 629 (1977) 20-29.

URL http://bit.1y/1oDMekI

[72] U. Angst, B. Elsener, C. K. Larsen, O. Vennesland, Critical chloride content in reinforced concrete -A review, Cement and Concrete Research 39 (2009) 1122-1138.

URL http://www.sciencedirect.com/science/article/pii/S0008884609002099

[73] Standard test method for acid-soluble chloride in mortar and concrete: ASTM C1152M - 04 (2006).

[74] K. Tuutti, Corrosion of steel in concrete, Swedish Cement and Concrete Research Institute, 1982.

URL http://www.lunduniversity.lu.se/o.o.i.s?id=12683\&postid=3173286

[75] G. Glass, N. Buenfeld, The presentation of the chloride threshold level for corrosion of steel in concrete, Corrosion Science 39 (5) (1997) 1001-1013.

URL http://www.sciencedirect.com/science/article/pii/S0010938X97000097

[76] G. Glass, B. Reddy, N. Buenfeld, Corrosion inhibition in concrete arising from its acid neutralisation capacity, Corrosion Science 42 (9) (2000) 1587-1598.

URL http://www.sciencedirect.com/science/article/pii/S0010938X00000081

[77] K. Y. Ann, H.-W. Song, Chloride threshold level for corrosion of steel in concrete, Corrosion Science 49 (11) (2007) 4113-4133.

URL http://www.sciencedirect.com/science/article/pii/S0010938X07001308

[78] D.A.Hausmann, Steel corrosion in concrete. How does it occur?, Materials Protection 6 (1967) $19-23$.

[79] D. Izquierdo, C. Alonso, C. Andrade, M. Castellote, Potentiostatic determination of chloride threshold values for rebar depassivation: Experimental and statistical study, Electrochimica Acta 49 (2004) 2731- 2739.

URL http://www.sciencedirect.com/science/article/pii/S0013468604002403

[80] C. Alonso, C. Andrade, M. Castellote, P. Castro, Chloride threshold values to depassivate reinforcing bars embedded in a standardized OPC mortar, Cement and Concrete Research 
30 (7) (2000) 1047-1055.

URL http://www.sciencedirect.com/science/article/B6TWG-419BFKV-6/2/ d7e721b43cfe0ba0b42a9f3ac69ee3d2

[81] E. Sheils, A. O'Connor, D. Breysse, F. Schoefs, S. Yotte, Development of a two-stage inspection process for the assessment of deteriorating infrastructure, Reliability Engineering \& System Safety 95 (3) (2010) 182-194.

URL http://www.sciencedirect.com/science/article/pii/S0951832009002282

[82] S. Bonnet, F. Schoefs, J. Ricardo, M. Salta, Effect of error measurements of chloride profiles on reliability assessment, in: 10th International conference on structural safety and reliability, 2009.

[83] Concrete, hardened: Accelerated chloride penetration: NT BUILD 443 (1995).

[84] J. Lizarazo-Marriaga, P. Claisse, Effect of the non-linear membrane potential on the migration of ionic species in concrete, Electrochimica Acta 54 (2009) 2761-2769.

URL http://www.sciencedirect.com/science/article/pii/S001346860801311X

[85] J. Lizarazo-Marriaga, P. Claisse, Determination of the concrete chloride diffusion coefficient based on an electrochemical test and an optimization model, Materials Chemistry and Physics 117 (2009) 536-543.

URL http://www.sciencedirect.com/science/article/pii/S0254058409003824

[86] E. Bastidas-Arteaga, Contribution for sustainable management of reinforced concrete structures subjected to chloride penetration, Ph.D. thesis, Université de Nantes (2010).

[87] Standard test method for electrical indication of concrete's ability to resist chloride ion penetration:ASTM C1202-10 (2010).

[88] C. Andrade, Calculation of chloride diffusion coefficientes in concrete from ionic migration measurements, Cement and Concrete Research 23 (1993) 724-742.

URL http://www.sciencedirect.com/science/article/pii/0008884693900233

[89] H. Friedmann, O. Amiri, A. Aït-Mokhtar, P. Dumargue, A direct method for determining chloride diffusion coefficient by using migration test, Cement and Concrete Research 34 (2004) 
$1967-1973$.

URL http://www.sciencedirect.com/science/article/pii/S0008884604000328

[90] Standard test method for determing the penetration of chloride ion into concrete by ponding:ASTM C1543-10A (2010).

[91] C. Arya, J. Newman, An assessment of four methods of determining the free chloride content of concrete, Materials and Structures 23 (1990) 319-330.

URL http://dx.doi.org/10.1007/BF02472710

[92] G. de Vera Almenar, Ingreso de cloruros en hormigón. métodos de análisis, detección no destructiva y modelización del transporte tras un aporte inicial limitado, Ph.D. thesis, Universitat d'Alacant (2000).

URL http://rua.ua.es/dspace/handle/10045/4124

[93] S. Muralidharan, R. Vedalakshmi, V. Saraswathi, J. Joseph, N. Palaniswamy, Studies on the aspects of chloride ion determination in different types of concrete under macro-cell corrosion conditions, Building and Environment 40 (9) (2005) 1275-1281.

URL http://www.sciencedirect.com/science/article/pii/S0360132304003087

[94] U. M. Angst, R. Polder, Spatial variability of chloride in concrete within homogeneously exposed areas, Cement and Concrete Research 56 (0) (2014) 40-51.

URL http://www.sciencedirect.com/science/article/pii/S0008884613002251

[95] S. Millard, Reinforced concrete resistivity measurement techniques, ICE Proceedings 91 (1991) $71-88$.

[96] K. Gowers, S. Millard, Measurement of concrete resistivity for assessment of corrosion severity of steel using wenner technique, ACI Materials Journal 96 (1999) 536-541.

URL http://bit.1y/1oDN1lJ

[97] B. Elsener, Macrocell corrosion of steel in concrete - Implications for corrosion monitoring, Cement and Concrete Composites 24 (2002) 65-72.

URL http://www.sciencedirect.com/science/article/pii/S0958946501000270

[98] F. Rajabipour, J. Weiss, J. Shane, T. Mason, S. Shah, Procedure to interpret electrical conductivity measurements in cover concrete during rewetting, Journal of Materials in Civil 
Engineering 17 (5) (2005) 586-594.

URL http://ascelibrary.org/doi/abs/10.1061/\%28ASCE $\% 290899-1561 \% 282005 \% 2917 \%$ $3 A 5 \% 28586 \% 29$

[99] C. Larsen, E. Sellevold, F. Askeland, J.-M. Østvik, O. Vennesland, Electrical resistivity of concrete part II: Influence of moisture content and temperature, in: 2nd International Symposium on Advances in Concrete through Science and Engineering. Quebec, Canada, 2006.

[100] P. Basheer, E. Nolan, W. McCarter, A. Long, Effectiveness of in situ moisture preconditioning methods for concrete, Journal of Materials in Civil Engineering 12 (2) (2000) 131-138.

URL http://ascelibrary.org/doi/abs/10.1061/\%28ASCE $\% 290899-1561 \% 282000 \% 2912 \%$ $3 \mathrm{~A} 2 \% 28131 \% 29$

[101] W. J. McCarter, G. Starrs, S. Knadasami, R. Jones, M. Chrisp, Electrode configurations for resistivity measurements on concrete, ACI Materials Journal 106 (2009) 258-264.

[102] R. Loubser Du Plooy, The development and combination of electromagnetic non-destructive evaluation techniques for the assessment of cover concrete condition prior to corrosion, Ph.D. thesis, Université de Nantes (2013).

[103] R. Falciai, A. Mignani, A. Vannini, Long period gratings as solution concentration sensors, Sensors and Actuators B: Chemical 74 (2001) 74-77.

URL http://www.sciencedirect.com/science/article/pii/S0925400500007140

[104] X. Shu, B. A. Gwandu, Y. Liu, L. Zhang, I. Bennion, Sampled fiber bragg grating for simulataneous refractive-index and temperature measurement, Optics Letters 26 (2001) 774-776. URL http://dx.doi.org/10.1364/OL.26.000774

[105] M. Keddam, H. Takenouti, X. R. Nóvoa, C. Andrade, C. Alonso, Impedance measurements on cement paste, Cement and Concrete Research 27 (1997) 1191-1201.

URL http://www.sciencedirect.com/science/article/pii/S0008884697001178

[106] D. A. Koleva, J. H. W. de Wit, K. van Breugel, L. P. Veleva, E. van Westing, O. Copuroglu, A.L.A.Fraaij, Correlation of microstructure, electrical properties and electrochemical phenomena in reinforced mortar. breakdown to multi-phase interface structures. Part II: Pore network, electrical properties and electrochemical response, Materials Characterization 59 
(2008) 801-815.

URL http://www.sciencedirect.com/science/article/pii/S1044580307002495

[107] I. Sánchez, X. R. Novoa, G. de Vera, M. A. Climent, Microstructural modifications in portland cement concrete due to forced ionic migration tests. study by impedance spectroscopy, Cement and Concrete Research 38 (2008) 1015-1025.

URL http://www.sciencedirect.com/science/article/pii/S0008884608000604

[108] R. Vedalakshmi, R. Devi, B. Emmanuel, N. Palaniswamy, Determination of diffusion coefficient of chloride in concrete: an electrochemical impedance spectroscopic approach, Materials and Structures 41 (7) (2008) 1315-1326.

URL http://dx.doi.org/10.1617/s11527-007-9330-1

[109] R. Vedalakshmi, V. Saraswathy, H.-W. Song, N. Palaniswamy, Determination of diffusion coefficient of chloride in concrete using warburg diffusion coefficient, Corrosion Science 51 (2009) 1299-1307.

URL http://www.sciencedirect.com/science/article/pii/S0010938X09001115

[110] Z. Sbartaï, S. Laurens, J.-P. Balayssac, G. Arliguie, G. Ballivy, Ability of the direct wave of radar ground-coupled antenna for $\{\mathrm{NDT}\}$ of concrete structures, $\{\mathrm{NDT}\} \&$ E International 39 (5) (2006) 400-407.

URL http://www.sciencedirect.com/science/article/pii/S0963869505001684

[111] Z. Sbartaï, S. Laurens, J. Rhazi, J. Balayssac, G. Arliguie, Using radar direct wave for concrete condition assessment: Correlation with electrical resistivity, Journal of Applied Geophysics 62 (4) (2007) 361-374.

URL http://www.sciencedirect.com/science/article/pii/S0926985107000237

[112] J. Hugenschmidt, R. Loser, Detection of chlorides and moisture in concrete structures with ground penetrating radar, Materials and Structures 41 (4) (2008) 785-792.

URL http://dx.doi.org/10.1617/s11527-007-9282-5

[113] A. Robert, Dielectric permittivity of concrete between $50 \mathrm{mhz}$ and $1 \mathrm{ghz}$ and \{GPR $\}$ measurements for building materials evaluation, Journal of Applied Geophysics 40 (1998) 89-94. URL http://www.sciencedirect.com/science/article/pii/S0926985198000093 
[114] U. B. Halabe, H.-L. Chen, V. Bhandarkar, , Z. Sami, Detection of sub-surface anomalies in concrete bridge decks using ground penetrating radar, ACI Materials Journal 94 (5) (1997) 396-408.

URL http://bit.1y/1mAehNm

[115] Z. Sbartaï, S. Laurens, K. Viriyametanont, J. Balayssac, G. Arliguie, Non-destructive evaluation of concrete physical condition using radar and artificial neural networks, Construction and Building Materials 23 (2) (2009) 837-845.

URL http://www.sciencedirect.com/science/article/pii/S0950061808000937

[116] D. Montgomery, Design and Analysis of Experiments, John wiley \& Sons, INC., 2001, Ch. Introduction, pp. 1-20.

[117] R. K. Leach, Fundamental principle of engineering nanometrology, Elsevier, 2010, Ch. Some basics of measurement, pp. $5-35$.

URL http://www.sciencedirect.com/science/book/9780080964546

[118] F. Schoefs, A. Clément, A. Nouy, Assessment of ROC curves for inspection of random fields, Structural Safety 31 (5) (2009) 409-419.

URL http://www.sciencedirect.com/science/article/pii/S0167473009000034

[119] H.-P. Loock, P. D. Wentzell, Detection limits of chemical sensors: Applications and misapplications, Sensors and Actuators B: Chemical 173 (0) (2012) 157-163.

URL http://www.sciencedirect.com/science/article/pii/S0925400512006466

[120] G. Villain, Z. M. Sbartaï, X. Dérobert, V. Garnier, J.-P. Balayssac, Durability diagnosis of a concrete structure in a tidal zone by combining $\{\mathrm{NDT}\}$ methods: Laboratory tests and case study, Construction and Building Materials 37 (2012) 893-903, non Destructive Techniques for Assessment of Concrete.

URL http://www.sciencedirect.com/science/article/pii/S0950061812001882

[121] F. Schoefs, J. Boéro, A. Clément, B. Capra, The alpha delta method for modelling expert judgement and combination of non-destructive testing tools in risk-based inspection context: application to marine structures, Structure and Infrastructure Engineering 8 (6) (2012) 531543.

URL http://dx.doi.org/10.1080/15732479.2010.505374 
[122] La norme béton: NF EN 206-1 (2000).

[123] E. Sheils, A. O'Connor, F. Schoefs, D. Breysse, Investigation of the effect of the quality of inspection techniques on the optimal inspection interval for structures, Structure and Infrastructure Engineering 8 (6) (2012) 557-568.

URL http://dx.doi.org/10.1080/15732479.2010.505377

[124] K. Ann, S.-W. Pack, J.-P. Hwang, H.-W. Song, S.-H. Kim, Service life prediction of a concrete bridge structure subjected to carbonation, Construction and Building Materials 24 (8) (2010) $1494-1501$.

URL http://www.sciencedirect.com/science/article/pii/S0950061810000358 